OPEN ACCESS

Edited by:

Gaiti Hasan

National Centre for Biological Sciences, India

Reviewed by: Aurnab Ghose,

Indian Institute of Science Education and Research (IISER) Pune, India Raghu Padinjat, National Centre for Biological Sciences, India

*Correspondence: Lisbeth Birk Møller lisbeth.birk.moeller@regionh.dk

Received: 13 September 2015 Accepted: 06 November 2015 Published: 18 December 2015

Citation:

Lenartowicz M, Krzeptowski W, Lipiński P, Grzmil P, Starzyński R, Pierzchała O and Møller LB (2015) Mottled Mice and Non-Mammalian Models of Menkes Disease.

Front. Mol. Neurosci. 8:72. doi: $10.3389 /$ fnmol.2015.00072

\section{Mottled Mice and Non-Mammalian Models of Menkes Disease}

\author{
Małgorzata Lenartowicz ${ }^{1}$, Wojciech Krzeptowski ${ }^{2}$, Paweł Lipiński ${ }^{3}$, Paweł Grzmil ${ }^{1}$, \\ Rafał Starzyński ${ }^{3}$, Olga Pierzchała ${ }^{1}$ and Lisbeth Birk Møller ${ }^{4 *}$ \\ ${ }^{1}$ Department of Genetics and Evolution, Institute of Zoology, Jagiellonian University, Kraków, Poland, ${ }^{2}$ Department of Cell \\ Biology and Imaging, Institute of Zoology, Jagiellonian University, Kraków, Poland, ${ }^{3}$ Department of Molecular Biology, \\ Institute of Genetics and Animal Breeding, Polish Academy of Sciences, Wólka Kosowska, Poland, ${ }^{4}$ Applied Human \\ Molecular Genetics, Kennedy Center, Rigshospitalet, Copenhagen University Hospital, Glostrup, Denmark
}

Menkes disease is a multi-systemic copper metabolism disorder caused by mutations in the X-linked ATP7A gene and characterized by progressive neurodegeneration and severe connective tissue defects. The ATP7A protein is a copper (Cu)-transporting ATPase expressed in all tissues and plays a critical role in the maintenance of copper homeostasis in cells of the whole body. ATP7A participates in copper absorption in the small intestine and in copper transport to the central nervous system (CNS) across the blood-brain-barrier (BBB) and blood-cerebrospinal fluid barrier (BCSFB). $\mathrm{Cu}$ is essential for synaptogenesis and axonal development. In cells, ATP7A participates in the incorporation of copper into Cu-dependent enzymes during the course of its maturation in the secretory pathway. There is a high degree of homology ( $>80 \%)$ between the human ATP7A and murine Atp7a genes. Mice with mutations in the Atp7a gene, called mottled mutants, are well-established and excellent models of Menkes disease. Mottled mutants closely recapitulate the Menkes phenotype and are invaluable for studying Cumetabolism. They provide useful models for exploring and testing new forms of therapy in Menkes disease. Recently, non-mammalian models of Menkes disease, Drosophila melanogaster and Danio rerio mutants were used in experiments which would be technically difficult to carry out in mammals.

Keywords: Menkes disease, ATP7A, copper metabolism, mottled mice

\section{INTRODUCTION}

Animal models are valuable tools for studying the role of copper $(\mathrm{Cu})$ in various physiological, as well as pathological processes, such as neuro- and embryo development, inflammation and cancer (Lutsenko et al., 2007; Barry et al., 2010; Collins and Klevay, 2011). Over the last two decades, major progress has been made in our understanding of the molecular basis of $\mathrm{Cu}$ homeostasis, as well as in identifying the structure and function of $\mathrm{Cu}$-containing proteins, largely thanks to animal models (Barry et al., 2010; Collins and Klevay, 2011; Telianidis et al., 2013).

\section{MOTTLED MICE AS AN ANIMAL MODEL FOR MENKES DISEASE}

Much of our knowledge originates from studies on mice with mutations in the mottled locus encoding the Atp7a gene (Kodama et al., 1993; Iwase et al., 1996; Kuo et al., 1997; La Fontaine et al., 1999; Niciu et al., 2007; Lenartowicz et al., 2010). Mouse models of 
Atp7a dysfunction are of particular importance for medical studies because mutations in the homolog human gene, ATP7A lead to the metabolic syndrome called Menkes disease, a fatal metabolic syndrome in humans (Menkes et al., 1962). The humane gene ATP7A and the murine gene Atp7a are both located on the X-chromosomes, and encode proteins called ATP7A, which belong to the P-type ATPase family. ATP7A transports $\mathrm{Cu}$ across membranes. During the catalytic cycle, ATP7A is autophosphorylated at a conserved aspartic acid and subsequently binds $\mathrm{Cu}$ to transmembrane domains. After releasing $\mathrm{Cu}$, ATP7A is dephosporylated. ATP7A is located in the trans-Golgi network (TGN) in the absence of $\mathrm{Cu}$, but recycles to the plasma membrane in the presence of $\mathrm{Cu}$. It is assumed that ATP7A located in the TGN is involved in loading $\mathrm{Cu}$ on to $\mathrm{Cu}$-requiring enzymes, whereas ATP7A located in the plasma is involved in extruding $\mathrm{Cu}$ from the cell. The two genes, ATP7A and Atp7a have a high degree of homology ( $>80 \%$; Reed and Boyd, 1997; Kim and Petris, 2007).

The absence of a functional ATP7A transporter does not alter the $\mathrm{Cu}$ uptake, but greatly reduces the efflux of $\mathrm{Cu}$ ions to the extracellular environment (La Fontaine and Mercer, 2007; Lutsenko et al., 2007). ATP7A is the key mediatorprotein involved in $\mathrm{Cu}$ transport across epithelial and endothelial cell barriers, and is therefore crucial for processes such as intestinal absorption and renal reabsorption of $\mathrm{Cu}$ and the ability of $\mathrm{Cu}$ to cross the blood-brain-barrier (BBB; Lutsenko et al., 2007). About 370 mutations have been identified in the ATP7A gene in humans, resulting in 3 different clinical phenotypes of Menkes disease: (1) Classical Menkes disease: patients with severe symptoms including mental retardation who die in early childhood (before the age of 6 years); (2) atypical Menkes disease: patients with less severe symptoms who live until adolescence; and (3) Occipital Horn Syndrome: patients with normal or near-normal neurological functions, milder symptoms, predominantly connective tissue problems, who live up to mid-adulthood. Furthermore mutations in ATP7A has also been associated with distal X-linked distal motor neuropathy (DMN; Kennerson et al., 2010) referred also as X-linked spinal muscular atrophy type 3 (SMAX-3; Yi and Kaler, 2014). Two different mutations leading to DMN has so far been identified (P1386S and T994I). Symptoms appeared when the patient was between 5 and 50 years of age and include gait instability with progressive weakness in feet and legs and loss of hand muscles. In contrast to Menkes disease DMN is not associated with symptoms of systemic copper deficiency.

A sequence alignment between mouse and human ATP7A proteins is given in Figure 1. The amino acids sequences within functional domains are highly conserved between human and mouse ATP7A (Figure 1). Even between mouse, human, zebra fish and fruit fly ATP7A/ATP7 proteins, the functional domains are highly conserved, as demonstrated in supplementary Figure 1.

Mice with mutations in the Atp7a gene are called mottled mutants reflecting the pattern of coat pigmentation in heterozygous females (Cecchi and Avner, 1996). Similarly to the large number of mutations in the human ATP7A gene, there are several murine strains with different mutations. The first description of mottled mutations in mice appeared from 1953 when Fraser and co-authors reported that "two mice with mottled coats have been analyzed genetically" (Fraser et al., 1953) and primary defects in copper transport in mottled mutants were described by Hunt (1974). Now, more than 60 years later and according to the Mouse Genome Informatics database, 109 mottled alleles are known and nearly half of them $(n=63)$ were introduced by gene trapping. Many mottled mutants have arisen spontaneously $(n=24)$ or have been induced by chemical $(n=$ $7)$, chemical and radiation (4), radiation $(n=6)$, or targeted $(n=$ 7) mutagenesis. Hemizygous mottled males exhibit a severe and often lethal phenotype. In general, affected males belong to one of three classes of phenotypic severity: (1) Mutant males that die in utero; (2) mutant males that die in the 3rd week of postnatal life; and (3) mutant males that die within a few postnatal months. So far, mutations in the Atp7a gene have been characterized in 15 mottled mutants (Table 1, Figure 2). The phenotypic diversity of the mottled alleles is a valuable source of knowledge not only about the molecular basis of Menkes disease, but also about the role of $\mathrm{Cu}$ in prenatal development.

\section{Prenatal Lethal Mottled Mutants}

Eight of the strains have mutations that lead to death in utero (class 1). This confirms that $\mathrm{Cu}$ plays an essential role in prenatal development, as well as the role of ATP7A in prenatal $\mathrm{Cu}$ metabolism. It has been suggested that mutations in the class 1 mice completely abolish the presence of functional ATP7A protein leading to the lethality of hemizygous males and the appearance of several pathological symptoms in heterozygous females.

Mutations in three strains lead to the absence of at least one exon in the Atp7a mRNA (Table 1). Fetuses of dappled $\left(A t p 7 a^{m o-d p}\right)$ hemizygous males with the genomic deletion of exon 1, are seemingly devoid of any Atp7a mRNA. Mutants display anatomical abnormalities and die already between day 17 and 18 of gestation (Silvers, 1979; Mercer et al., 1994). Mottled spot $\left(\right.$ Atp $\left.7 a^{m o-s p o t}\right)$ mutants have a genomic deletion including exons 11-14 (Cunliffe et al., 2001). A base pair substitution at the donor splice site of intron 14 leads to a constitutive Skipping of exon 14 in 1 Pub (Atp7amo-pup; Cecchi and Avner, 1996). Male embryonic lethality at E11 of the tohoku mutants (Atp $7 a^{\text {mo-tohm }}$ ) is caused by a 1440-bp deletion between intron 22 and exon 23 of the Atp7a gene (Mototani et al., 2006).

Apart from deletions, vast insertions may also be responsible for lethality (Table 1). In candy (Atp7 $a^{m o-c a}$ ), an insertion of an 81 bp sequence similar to the transposable element LINE in exon 10 , leads to the activation of a cryptic splice site, resulting in a transcript that lacks the first $30 \mathrm{bp}$ of exon 10 (Cunliffe et al., 2001). Not surprisingly, the nonsense mutation (c.1492G $>\mathrm{T}$, p.Glu498*) in Atp $7 a^{m o-2 B t l r}$ is prenatally lethal. Some missense mutations also lead to prenatal lethality in mice (Table 1). Miss-localization of ATP7A to the endoplasmic reticulum and impaired glycosylation of the protein have been shown in $\mathrm{H} 11$ $\left(\right.$ Atp $\left.7 a^{m o 11-H}\right)$ mutants which were predicted to contain the amino acid substitution p.Ala1364Asp (Cunliffe et al., 2001; Kim and Petris, 2007). Also the missense mutation (c.2993C> T p.Ala998Val) leads to death in utero (REFJ: 133115). 


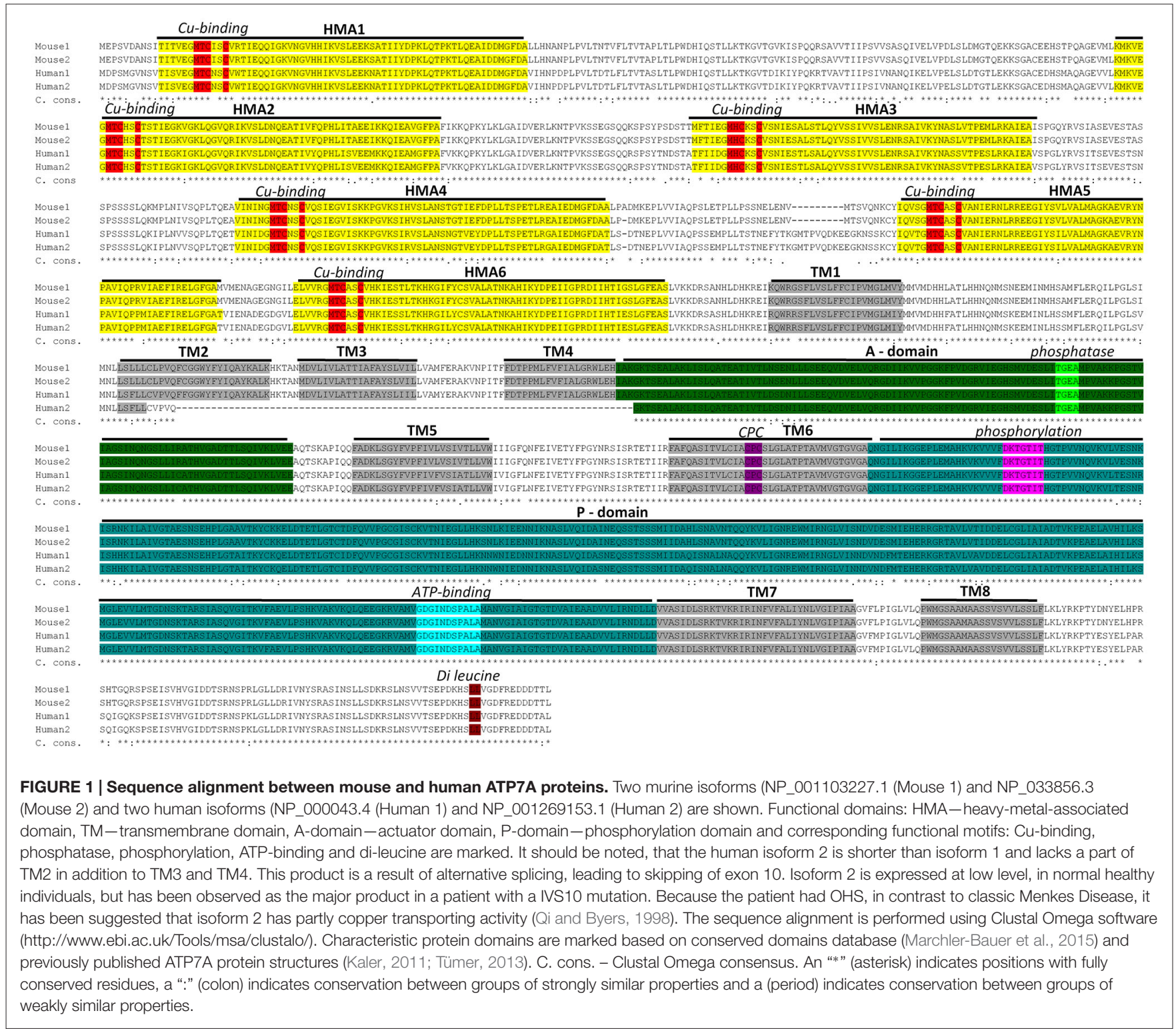

There is also a group of less well characterized, predominantly chemically induced, prenatally lethal mottled mutations, which result in very small amounts of Atp $7 a$ transcript (Cecchi et al., 1997).

Interestingly, whereas wide deletions in the Atp7a gene in mouse mutant males have a prenatal lethal effect, in humans about $15 \%$ of the mutations in the ATP7A gene, which are caused by large deletions, in great majority result in the classical, severe form of Menkes disease leading to death in early childhood ( $<6$ years; Poulsen et al., 2002; Tümer et al., 2003). It seems that even the most severe mutations in humans lead to a fullterm pregnancy and live birth. This clearly indicates that the mutational effects on human ATP7A and mouse Atp7a genes can be different. These differences may be due to different levels of efficiency of placental $\mathrm{Cu}$ transport or by higher demands in mice for $\mathrm{Cu}$ supply during development.

\section{Mice Models for Classical Menkes Disease}

Mutants belonging to the 2nd group are widely used for studies of $\mathrm{Cu}$ metabolism and serve as models of classical Menkes disease in humans. Especially brindled, mosaic and macular mice have been studied intensively. Although the genetic background of the three strains $\left(A t p 7 a^{m o-b r}\right),\left(A t p 7 a^{m o-m s}\right)$ and $\left(A t p 7 a^{m o-m l}\right)$ are different, their phenotypes are very similar (Table 1). In brindled mutants, the genetic defect is caused by the deletion of $6 \mathrm{bp}$ in exon 11 which leads to an in-frame deletion of the amino acids Ala799 and Leu800 located in the region between the fourth transmembrane domain and the transduction domain of ATP7A protein (Grimes et al., 1997; La Fontaine et al., 1999). Although the ATP7A protein level in brindled cells is very similar to that of control cells, $\mathrm{Cu}$ transport activity of the mutant proteins is extremely reduced. In the brindled cells, ATP7A is located in TGN independently of the Cu level (note the 


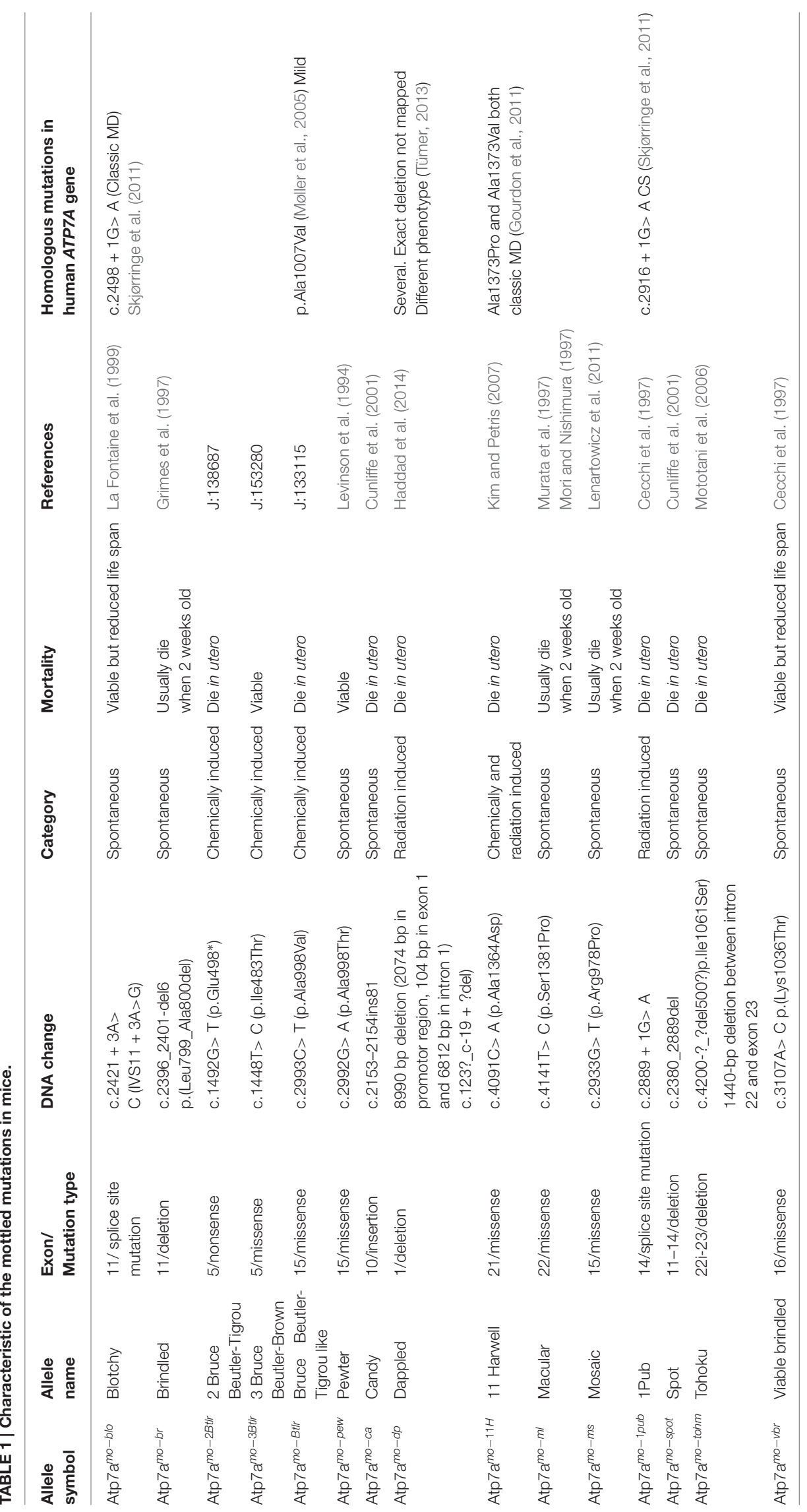


normally $\mathrm{Cu}$-dependent cellular trafficking; La Fontaine et al., 1999). In the mosaic mutants we identified the missense mutation c.2933G > C (p.Arg978Pro; Lenartowicz et al., 2012a; Table 1). Exon 15 encodes the highly conserved 6th transmembrane domain containing a CPC amino acid motif, which serves as a channel for $\mathrm{Cu}(\mathrm{I})$ transport and is critical for the protein function (Barry et al., 2010; van den Berghe and Klomp, 2010). In the mosaic mutants the ATP7A protein is mislocalized and is not translocated to the plasma membrane regardless of exposure of these cells to increased $\mathrm{Cu}$ concentrations (Lenartowicz et al., 2012a). Moreover, analysis of the coding region of the Atp7a gene in the mosaic mutants revealed the presence of the three additional nucleotides CAG (c.1417insCAG) at the end of exon 4 , leading to the addition of a Glutamine between the 4th and 5th Cu-binding domain. This insertion was also associated with alternative splicing of the 3' end of the exon 4 (Lenartowicz et al., 2004). However, this insertion was also found in other inbred strains of mice and is recognized as a polymorphism (Cecchi and Avner, 1996). Analysis of the coding region of the Atp7a gene in macular mutants revealed the mutation c.4223T $>C$ (p.Ser1382Pro) in the region encoding the conserved 8th transmembrane domain (Mori and Nishimura, 1997; Murata et al., 1997; Table 1). In the macular mutants, impaired $\mathrm{Cu}$ delivery to the secretory pathway is due to hyperphosphorylation of the ATP7A protein (Kim and Petris, 2007).

In mutants belonging to the 2nd group, the structure of the Atp7a gene is changed by missense mutations or small inframe deletions, which lead to the synthesis of mutated protein with significantly reduced but not completely abolished activity. Consequently, hemizygous brindled, mosaic and macular males manifest pathological symptoms characteristic of strong $\mathrm{Cu}$ deficiency, but they survive until about the 3rd week of life. Actually, even few brindled and mosaic mutant males survive a critical period and can achieve remarkable longevity (Silvers, 1979; Lenartowicz et al., 2002; Kowal et al., 2010). Mosaic mutants that survive are relatively small and display defects in pigmentation, but do not develop neurological symptoms (Lenartowicz et al., 2002).

\section{Mottled Models for Occipital Horn Syndrome}

Mutants of the 3rd group exhibit less severe phenotypes and survive to maturity. Mice in the 3rd group develop pathological symptoms similar to those described in patients with the atypical form of Menkes disease and with OHS. Patients with OHS have less profound neurological manifestations than those suffering from classical Menkes disease and their clinical features are mainly restricted to connective tissue defects. They also have a longer lifespan (Royce and Steinmann, 1990; Proud et al., 1996; Kaler, 1998; Godwin et al., 2006; Tang et al., 2006; Tümer and Møller, 2010).

Both viable-brindled and blotchy males manifest strong and numerous connective tissue abnormalities (Rowe et al., 1974; Das et al., 1995). The viable-brindled (Atp7amo-vbr $)$ mutants has the mutation c. $3107 \mathrm{~A}>\mathrm{C}$ in exon 16 (p.Lys1036Thr; Cecchi and Avner, 1996; Reed and Boyd, 1997). It results in constitutive
post-Golgi localization of ATP7A and is probably caused by hyperphosphorylation of the mutated protein and significantly reduced activity (Kim and Petris, 2007). Nevertheless, viablebrindled males suffer from aortic aneurysms, but they survive longer than mutants of the 2rd group, and succumb to blood vessel rupture at the age of 2-3 months (Rowe et al., 1974). Viable-brindled males are sterile.

The lifespan of blotchy males is the longest among mottled mutants. However these mutants suffer from emphysema, develop osteoarthrosis (Silberberg, 1977; Silvers, 1979), aortic and abdominal aneurysms due to defective elastin fibers (Silvers, 1979; Green, 1981). They usually die from a ruptured aorta at the age of more than 150 days (Rowe et al., 1974). Their average survival age is about 200 days and many live longer. Both blotchy males and females are usually infertile (Silvers, 1979). A splicedonor mutation is the cause of the defect in blotchy $\left(\right.$ Atp $7 a^{\text {mo-blo }}$ ) mice (Mercer et al., 1994; Das et al., 1995). The mutation (c.2421 $+3 \mathrm{~A}>\mathrm{C}$ ) in intron 11 leads to partial skipping of $92 \mathrm{bp}$ from exon 11 and results in a frame-shift (Mercer et al., 1994; Das et al., 1995; La Fontaine et al., 1999). Blotchy mutants produce, apart from inactive truncated forms, normal ATP7A protein, although in significantly reduced amounts. To explain the milder phenotype of the blotchy mutants it has been shown, that small amounts of the normal ATP7A protein are synthesized, which enables a limited $\mathrm{Cu}$ absorption and transport (La Fontaine et al., 1999). Similarly in humans, the less severe (atypical) form of Menkes disease and OHS are caused mainly by leaky splicesite mutations, permitting the production of small amounts of normal transcript (Møller et al., 2009; Skjørringe et al., 2011; Tümer, 2013). In humans, approximately $22 \%$ of mutations identified in ATP7A gene constitute splice-site mutations (Møller et al., 2009). However, splice-site mutations can also lead to the severe form of Menkes disease, if no normal transcript is produced (Skjørringe et al., 2011). In humans, an estimated $2-5 \%$ of wild-type transcript of the ATP7A gene, alleviates disease severity resulting in the OHS phenotype (Møller et al., 2000; Skjørringe et al., 2011).

The connective tissue abnormalities in the mutants are caused by decreased activity of lysyl oxidase which is responsible for connective tissue formation (Royce and Steinmann, 1990). Lysyl oxidase is a $\mathrm{Cu}$-containing extracellular enzyme which catalyzes the process of oxidative deamination of lysine or hydroxylysine residues within the collagen $\alpha$-chains, or of specific lysyl residues in elastin, to form the aldehyde precursors of the cross-links necessary to the formation of collagen and elastin (Royce and Steinmann, 1990; Rucker et al., 1998).

Significant reduction in lysyl oxidase activity has been demonstrated in skin and aorta (Royce and Steinmann, 1990) and in the medium of cultured fibroblasts obtained from OHS and Menkes patients (Kuivaniemi et al., 1985; Kemppainen et al., 1996).

It is interesting that blotchy mice have more pronounced connective tissue defects compared to brindled (2nd class mutant) despite blotchy mutants live much longer. Analysis of lysyl oxidase activity in extracts from the skin of 10-day old brindled and blotchy mutants revealed that the enzyme activity in brindled males was $50-60 \%$ of control level whereas it in blotchy 


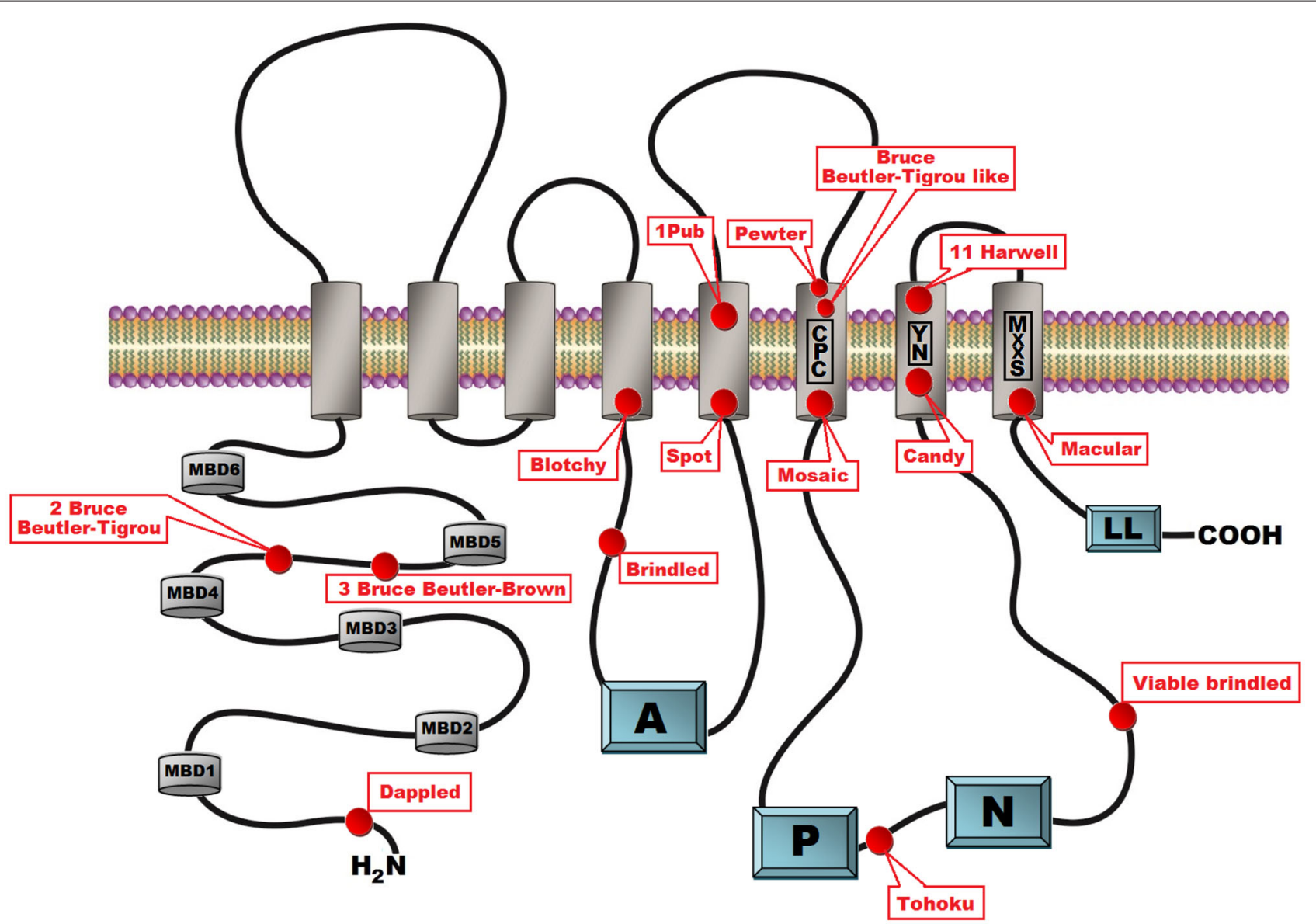

FIGURE 2 | Schematic presentation of the secondary structure of the ATP7A protein with location of the 15 mottled mutants indicated. ATP7A is a transmembrane protein anchored to the membrane of the Golgi apparatus with eight transmembrane domains. The CPC amino acid motif within the 6th transmembrane domain is assumed to play a direct role in copper ions translocation across the biological membrane. The $\mathrm{N}$-terminal peptide contains six cytoplasmic copper binding domains. Cytoplasmic domains are involved in the catalytic cycle that mediates cupric ions active transport at the cost of ATP hydrolysis. In the catalytic cycle ATP was bind to the nucleotide binding domains $(\mathrm{N})$ and after hydrolysis the $\gamma$-phosphate of ATP is transferred to the invariant aspartate residue in the in the phosphorylation domain (P). Energy released by ATP hydrolysis is utilized for ions transport across a membrane. The actuator domain (A) located between the 4th and 5th transmembrane domains plays a key role in the dephosphorylation of the phosphorylated protein. The amino terminal part of the protein contains a dileucine motif (LL) motif that is involved in retrograde transport to the trans Golgi network (TGN).

males only was about 30\% (Royce et al., 1982). This difference in lysyl oxidase activity may be explained by different molecular effect of the mutations. Whereas only small amount of wild type ATP7A is expressed in blotchy mutants as a result of a leaky splicesite mutation, normal amount of mutated ATP7A protein, trapped in TGN as described above, is expressed in brindled mutants (La Fontaine et al., 1999). The TGN trapped ATP7A protein probably allowed partial preservation of biosynthetic functions.

All mottled mutants exhibit defects in pigmentation caused by decreased activity of tyrosinase, a $\mathrm{Cu}$-dependent enzyme that is involved in the formation of melanin pigment (Petris et al., 2000). The catalytic domain of apo-tyrosinase has two Cu-binding sites, and catalytic activity of tyrosinase requires the incorporation of $\mathrm{Cu}$ into both sites. This process is mediated by ATP7A (Petris et al., 2000). That is why the fur of the mutant males is uniformly pale, and the coat pigmentation in heterozygous females, which are mutation carriers, displays an irregular pattern, probably due to X chromosome inactivation (Lyon, 1962). Decreased tyrosinase activity has been found in brindled (Grüneberg, 1969; Mercer et al., 1999), mosaic (Styrna, 1977) and macular (Yamano et al., 1987) mutants.

\section{Mice Models for X-Linked Distal Motor Neuropathy}

Conditional knockout mice with selective distruption of the Atp7a gene in motor neurons $\left(A t p 7 a^{M N / Y}\right)$ were used to explain the role of mutation in the ATP7A gene in development of DMN (Hodgkinson et al., 2015). Knockout mice have a normal lifespan and do not exhibit signs or symptoms of systemic copper deficiency characteristic for mottled mutants. They also have normal coat pigmentation. However during the lifespan knockout the mice developed gait defects, loss of 
limb strength, and muscle wasting, consistent with the disease progression observed in DMN patients (Hodgkinson et al., 2015).

\section{LESSONS FROM THE MOTTLED MICE}

\section{Cu Uptake and Distribution}

In agreement with the well established role of ATP7A as a transporter of $\mathrm{Cu}$ via the basolateral membrane of enterocytes (Lutsenko et al., 2007), the defective function of ATPase in mottled mice leads to the accumulation of $\mathrm{Cu}$ in the cytoplasm of the absorptive epithelial cells in the intestine (Camakaris et al., 1979; Shiraishi et al., 1988; Kodama, 1993; Nakagawa et al., 1993). Thus, results from studies in macular mice reveal a $\mathrm{Cu}$ accumulation in the cytoplasm of the intestinal epithelial cells and in the vascular endothelium (Kodama et al., 1993). This is consistent with the higher $\mathrm{Cu}$ level found in the small intestine of the brindled (Prohaska, 1983) and mosaic mutants (Lenartowicz and Sasuła, 2000). The molecular machinery involved in intestinal $\mathrm{Cu}$ transport and its regulation during early life in healthy mice is poorly understood.

In mice, the expression of the Atp7a gene begins early in prenatal life. Atp7a expression has been detected in only 7-dayold mouse embryos (Cecchi and Avner, 1996). It has been shown that its expression is ubiquitous during embryogenesis from day 9.5-18.5 (Kuo et al., 1997). Postnatally, Atp7a is expressed in all tissues and organs and Atp7a was categorized as a house-keeping gene (Linz and Lutsenko, 2007; Lutsenko et al., 2007). However, the expression level differs between organs and changes during the lifespan (Lenartowicz et al., 2011).

The pattern of $\mathrm{Cu}$ distribution in tissues from mouse models of Menkes disease cannot be classified as a general, systemic $\mathrm{Cu}$ deficiency. Several tissues such as kidney, intestine, placenta, and testis, have been shown to accumulate excessive or even toxic amounts of $\mathrm{Cu}$ (Prohaska, 1983, 1988; Phillips et al., 1986; Nakagawa et al., 1993; Lenartowicz and Sasuła, 2000; Kowal et al., 2010). This is very likely connected to the specific function of ATP7A in several cell types, which consists of expelling $\mathrm{Cu}$ from cells to the extracellular environment. Consequently, dysfunctional ATP7A in absorptive enterocytes and syncytiotrophoblasts does not only lead to the accumulation of $\mathrm{Cu}$ in these cells, but also limits this metal to other cells in the body. Furthermore, because ATP7A plays an imported roles in the delivery of $\mathrm{Cu}$ to $\mathrm{Cu}$-containing enzymes, a large number of essential enzymes are left dysfunctional.

\section{Cu Delivery to the Foetus}

During pregnancy, $\mathrm{Cu}$ is transported from the maternal to the foetal circulation via the placenta. This process is mediated by ATP7A and the homologous Cu-transporting ATPase, ATP7B (Hardman et al., 2007; La Fontaine and Mercer, 2007). It has been proposed that ATP7A plays a key role in Cu delivery to the foetus across the basolateral surface of the syncytiotrophoblast layer (Hardman et al., 2004, 2007), as an increase in the placental
$\mathrm{Cu}$ content is observed in the brindled and macular mouse, and a direct blockage of placental transport has been demonstrated in these mouse models (Kasama and Tanaka, 1989; Xu et al., 1994).

Decreased transport of $\mathrm{Cu}$ across the placenta is probably the first reason for substantially reduced $\mathrm{Cu}$ content in the brain of 1-day-old mosaic mutant mice (Lenartowicz et al., 2011). Interestingly, wild-type mice and mosaic mutants show two different profiles of $\mathrm{Cu}$ content in the brain during early development (first 2 weeks after birth) i.e., a substantial increase is observed in wild-type mice, whereas no changes are found in mutants. This indicates that neonatal $\mathrm{Cu}$ deficiency in the brain of mutants just after birth is further aggravated throughout the early development (Lenartowicz et al., 2011).

\section{Cu Disturbance in the Brain}

Menkes disease is commonly considered as a neurodegenerative, $\mathrm{Cu}$ deficiency disorder (Tümer and Møller, 2010; Kodama et al., 2012). In humans, $\mathrm{Cu}$ content in the brain ( $~ 5 \mu \mathrm{g} / \mathrm{g}$ tissue) is among the highest in various tissues (Collins and Klevay, 2011). This high $\mathrm{Cu}$ concentration is related to the metabolic activity of many $\mathrm{Cu}$-dependent enzymes that function in the brain, such as cytochrome $c$ oxidase, peptidylglicine alpha-amidating monooxygenase (PAM), dopamine-beta monooxygenase (DBH) and $\mathrm{Cu}, \mathrm{Zn}$-superoxide dismutase (SOD1; Suzuki and Gitlin, 1999; Prohaska and Broderius, 2006; Lutsenko et al., 2007; Nelson and Prohaska, 2009).

The ATP7A gene is highly expressed in the ependymal cells of the choroid plexus, a structure that regulates the concentration of the different molecules in the cerebro-spinal fluid, and the ATP7A protein is suggested to be involved in $\mathrm{Cu}$ transport across the BBB (Iwase et al., 1996; Niciu et al., 2006; Lutsenko et al., 2007). Copper deficiency in the central nervous system (CNS) of the Menkes patients lead to delay of their physical and mental development. In Menkes patients and mottled mutants, $\mathrm{Cu}$ accumulates in the cells comprising the blood-brain barrier and choroid plexus and is not transported from blood vessels to neuronal tissue (Kodama et al., 2005, 2012; Donsante et al., 2010, 2011). The severe decrease in $\mathrm{Cu}$ content in the brain and resulting deficiencies in the activity of $\mathrm{Cu}$-containing enzymes are the main reasons for the early fatality in Menkes patients as well as in mottled mice.

ATP7A is especially abundant in the early postnatal period during brain development, because its activity is critical for proper axonal development and extension, and for synaptogenesis (El Meskini et al., 2005; Niciu et al., 2006, 2007). In the brain, ATP7A is expressed not only in the neurons, but also in a subset of astrocytes, microglia, oligodendrocytes, tanycytes and endothelial cells (Niciu et al., 2006, 2007). Neuropathological changes caused by mutations in the Atp7a gene are best characterized in brindled mutants. Due to the lack of activity of Atp7a in the brain of the brindled mutants the $\mathrm{Cu}$ content is 2-4 folds lower when compared to wild-genotype mice (Camakaris et al., 1979; Phillips et al., 1986). Detailed analysis of Atp7a/ATP7A expression patterns 
indicates that in the mutant's brain, both transcript and protein levels are reduced in Purkinje cells, hippocampal pyramidal neurons and surrounding interneurons (Niciu et al., 2007). It resulted in the presence of numerous pycnotic neurons in the cerebral cortex and hippocampus in the brindled mutants (Niciu et al., 2007; Donsante et al., 2011). Electron microscopy examination of the Purkinje cells structure revealed cytoskeleton disruption, with tortuous, bulbous axons terminating abruptly in the cerebellar cortex (Niciu et al., 2007; Donsante et al., 2011). This explains why brindled, mosaic and macular mutant males in the 2 nd week of life manifest severe neurological symptoms such as tremors, ataxia and seizures (Phillips et al., 1986; Kodama et al., 2005; Niciu et al., 2006; Lenartowicz et al., 2012a).

Interesting, neonates Menkes patients do not exhibit any neurological symptoms but patients older than 2 months developed seizures, prominent hypotonia and failure to thrive (Tümer and Møller, 2010; Kaler, 2011). Almost all Menkes patients older than 2 months developed epilepsy. Seizure types include focal or multifocal tonic-clonic, myoclonic, infantile spasms, and status epilepticus (White et al., 1993; BahiBuisson et al., 2006; Kaler et al., 2010). Electroencephalographic (EEG) analysis indicated that those patients exhibit abnormal electrocerebral activity (Kaler et al., 2008, 2010). Results obtained by Kaler et al. (2010) indicated that patients, who were presymptomatic diagnosed and early treated with copper injection ( $\leq 6$ weeks of age), had decreased occurrence of seizures and improved brain electrical activity. In Menkes patients, magnetic resonance imaging (MRI) revealed neuropathological abnormalities including diffuse atrophy, ventriculomegaly, delayed myelination and tortuosity of cerebral blood vessels (Kaler et al., 2008; Kaler, 2011). Pathological changes are especially found in the cerebral cortex and the cerebellum, and include loss of Purkinje cells and neuronal loss of cerebellar molecular and internal granule cell layers (Kodama et al., 2012). In addition, subdural hematomas occurs secondary to abnormalities in brain arteries due to decreased activities of lysyl oxidase, which causes neurological damage (Kodama et al., 2012).

In the mottled mutants, neurological symptoms can also be caused by disturbances in neurotransmitter production. The $\mathrm{Cu}-$ dependent enzyme, $\mathrm{DBH}$, catalyze the conversion of dopamine to noradrenaline which is metabolized to adrenaline. In the cells of patients with Menkes disease, the activity of $\mathrm{DBH}$ is significantly diminished and cannot be improved by parenteral $\mathrm{Cu}$ administration (Christodoulou et al., 1998). These findings indicate that $\mathrm{Cu}$ cannot be incorporated into the apo form of $\mathrm{DBH}$ in $\mathrm{MD}$-affected cells because of ATP7A deficiency (Kodama et al., 2005). Reduced DBH activity is also found in the brain of brindled and macular mutants (Wenk and Suzuki, 1983; Kodama et al., 2005; Niciu et al., 2006; Bhadhprasit et al., 2012). The ratio of noradrenaline to dopamine and adrenaline to dopamine in these mutants is low when compared to wildgenotype controls (Kodama et al., 2005; Donsante et al., 2011, 2013; Bhadhprasit et al., 2012).

Another enzyme containing two $\mathrm{Cu}$-centers which cycles between the $\mathrm{Cu}(\mathrm{I})$ and $\mathrm{Cu}(\mathrm{II})$ states during catalysis, is PAM
(Steveson et al., 2003; Otoikhian et al., 2012). PAM catalyzes the C-terminal amidation of about $50 \%$ of all glycine-extended neuropeptides (Steveson et al., 2003; Bousquet-Moore et al., 2010). Such modification is essential for the bioactivity of numerous hormones and neuropeptides because it prevent $\mathrm{COOH}$-terminus ionization and rendering it more hydrophobic. Such modification allow for better binding of $\alpha$-amidated peptides to its receptors (Eipper et al., 1992, 1993; BousquetMoore et al., 2010). Lack of PAM activity in the $\mathrm{PAM}^{-/-}$mice, lead to lethality during the prenatal life (Bousquet-Moore et al., 2010; Gaier et al., 2013b). Heterozygous $\mathrm{PAM}^{+/-}$mice are fertile but developed pathological symptoms such as behavioral deficits, problems with thermoregulations and increased sensitivity to drug-induced seizures (Bousquet-Moore et al., 2010; Gaier et al., 2013b) and disturbance of copper metabolism in the brain (Gaier et al., 2013b). ATP7A co-locates with PAM in the intracellular compartments and is required for the maturation of this cuproprotein by metallation with $\mathrm{Cu}$ ions in TGN (Steveson et al., 2003; El Meskini et al., 2005; Otoikhian et al., 2012). In the brain of 12-day-old brindled mice, the expression level of PAM protein is similar to control mice, but the activity is reduced. In the brindled mutants it is manifested by reduced amidation of joining peptides, (JP- $\left.\mathrm{NH}_{2}\right)$, cholecystokinin (CCK) and a diminished level of alpha-melanotropin (alpha-MSH). Thus, the lack of amidated peptides in many target tissues, at crucial periods during the development, could contribute to the disease phenotype (Steveson et al., 2003; Niciu et al., 2007).

Epilepsy and seizures in Menkes patients and mottled mutants can be multifactorial processes connected with decreased copper contents in the CNS leading to deficits in neurotransmitter function, altered energy metabolism, and excitotoxicity (Prasad et al., 2011; Gaier et al., 2013a; Verrotti et al., 2014). It is known that some process of neural excitation and inhibition are modulated by amidated peptides (Bousquet-Moore et al., 2010). In vitro analysis of hippocampus slices indicated that the thyrotropin hormone-releasing hormone (TRP) reduce neuronal excitation by inhibition of potassium-stimulated glutamate and aspartate release. TRP analog administration reduce seizures (Nie et al., 2005; Veronesi et al., 2007; Bousquet-Moore et al., 2010). Results of immunostaining analysis indicated that both ATP7A and PAM highly expressed in the GABAergic neurons (Gaier et al., 2013b). Decreasing activity of PAM in the brain of the mottled mutants can lead to impaired production of amidated neuropeptide Y (NPY) and can be responsible for seizures. NPY decrease glutamate release and results obtained by Richichi and co-workers indicated that both acute and chronic seizures can be reduced by increasing NPY expression in the hippocampus (Richichi et al., 2004; Bousquet-Moore et al., 2010). Macular and brindled mutants also exhibit reduced cerebral cytochrom c oxidase activity (Donsante et al., 2011; Munakata et al., 2012).

The conditional knockout mice with selective disruption of Atp7a gene in motor neuron were very useful in evaluating the role of the ATP7A protein in normal motor neuron function. In $\left(A t p 7 a^{M N / Y}\right)$ knockout mice deletion of Atp7a resulted in disturbances of copper transport; copper concentration in the 
motor neurons increased with concomitant decreasing of $\mathrm{Cu}$ contents in the spinal cord. Accumulation of copper in the motor neurons lead to degeneration of the neuron cells and especially interesting degeneration process begins in the distal portions of axons and retreats towards the cell body (Hodgkinson et al., 2015). This pattern of neuron loss leads to denervation of the neuromuscular junctions and finally to muscular atrophy (Hodgkinson et al., 2015).

\section{Hepatic $\mathrm{Cu}$}

Examples from studies on iron absorption in rodents clearly show that the expression of the main apical and basolateral iron transporters in the duodenum is very low during the neonatal period (reviewed by Lipiński et al., 2013). Interestingly, in mice, the divalent metal transporter 1 (DMT1/Nramp2), is proposed in addition to functioning as an apical ferrous iron transporter (Lutsenko et al., 2007) to play a relevant role in physiological $\mathrm{Cu}$ absorption (Arredondo et al., 2003). DMT1 is barely detectable at postnatal days 0 and 5, but by day 10 this transporter is predominantly localized in the apical membrane of the maturing intestine (Lopez et al., 2006). Similarly to iron, the initial hepatic $\mathrm{Cu}$ stores established through maternal-fetal transfer, determine the iron status of the newborn.

$\mathrm{Cu}$ accumulated in the foetal liver during the second half of prenatal development is a primary source of this metal for meeting the needs of the organism during neonatal period (McArdle and Erlich, 1991; Mercer et al., 1992). Studies on mosaic mutants clearly show that the $\mathrm{Cu}$ content is significantly decreased already on day 1 after birth and persists at low level up to day 14 (Lenartowicz et al., 2011). An early decrease in hepatic $\mathrm{Cu}$ concentration has also been reported in other mouse models of Menkes disease (Prohaska, 1983; Phillips et al., 1986; Nakagawa et al., 1993). Considering that the liver is an organ that plays a role in the redistribution of $\mathrm{Cu}$ around the body, hepatic $\mathrm{Cu}$ scarcity in early development may result in restricted $\mathrm{Cu}$ supply from the liver to other tissues and organs including brain, heart or muscles. We recently reported the presence of low $\mathrm{Cu}$ levels in peripheral erythrocytes of 14-day-old mosaic male mice. This decrease strongly correlates with the down-regulation of both expression and activity of the $\mathrm{Cu}$-dependent antioxidant enzyme SOD1, playing a crucial role in erythrocyte antioxidant defense. SOD1 dysfunction results in oxidative stress, increased fluidity of erythrocyte membranes and hemeolysis (Lenartowicz et al., 2014).

\section{$\mathrm{Cu}$ in the Kidney}

A toxic $\mathrm{Cu}$ accumulation in the kidney is observed in most mouse models of Menkes disease (Suzuki-Kurasaki et al., 1997; Kirby et al., 1998; Lenartowicz et al., 2001, 2010). There is evidence that in mottled mice, renal epithelial cells of proximal tubules are the primary sites of $\mathrm{Cu}$ toxicity (Suzuki-Kurasaki et al., 1997; Kirby et al., 1998). Available data suggest a likely mechanism for this $\mathrm{Cu}$ overload. In the kidneys of healthy animals, $\mathrm{Cu}$ reabsorption from the urine occurs via the proximal renal tubules. The $\mathrm{Cu}$ ions are transferred back to the circulation via ATP7A, located in the basolateral membranes of epithelial cells of these tubules. This explains why the dysfunction of the ATP7A protein results in toxic $\mathrm{Cu}$ accumulation at the renal-proximal epithelium (Suzuki-Kurasaki et al., 1997; Kirby et al., 1998; Lenartowicz et al., 2010). Our previous results indicated that $\mathrm{Cu}$ accumulation in the kidney starts in prenatal life because the $\mathrm{Cu}$-concentration in the only 1-day-old mice was higher than in wild-genotype mice (Lenartowicz et al., 2011). An increase in the $\mathrm{Cu}$ level in the kidney of the 18-day-old macular fetus was also found by others (Kasama and Tanaka, 1989). We also noticed that the $\mathrm{Cu}$ accumulation process in the kidney is strongly enhanced during the postnatal life of the mutants, because in 1-day-old mosaic males the $\mathrm{Cu}$ level was increased twofold, whereas it was increased fourfold in 14day-old mutants when compared to control mice (Lenartowicz et al., 2010). It is noteworthy that $\mathrm{Cu}$ is even more active than iron in catalyzing the Fenton reaction. It is not surprising therefore that the kidneys of mouse Atp7a mutants display a large range of oxidative damage. Pathological changes involve renal tubules and glomeruli damage. In some cases the changes are very serious with renal tubules necrosis and sclerosis of renal glomeruli (Lenartowicz et al., 2002, 2010). Although renal pathology is not a direct cause of death in mottled mice, it constitutes a serious problem during $\mathrm{Cu}$ therapy. Parenteral supplementation with $\mathrm{Cu}$ prevents early death of mice, but at the same time it increases renal $\mathrm{Cu}$ content and strongly exacerbates kidney dysfunction (Lenartowicz et al., 2001, 2010). Treatment with $\mathrm{Cu}$ alone in postnatal life results in an up to 10-fold increase of $\mathrm{Cu}$ in the kidney of 14day-old mutants when compared to untreated mosaic mice (Lenartowicz and Sasuła, 2000). The high $\mathrm{Cu}$ concentration persists during the life span of the treated mutants (Lenartowicz et al., 2010).

\section{Mottled Mice and Menkes Disease Therapy}

Effective therapy is still a topical problem in Menkes disease. Treatment of Menkes patients with daily $\mathrm{Cu}$ injections may relieve the symptoms, as long as it is started within a few days after birth (Kaler et al., 2008; Tümer and Møller, 2010; Kodama et al., 2011, 2012). However, in the severe form of classic Menkes disease, even early $\mathrm{Cu}$ therapy is not always effective, and does not protect patients from neurological and connective tissue damage (Nadal and Baerlocher, 1988; Kaler et al., 1995; Choi and Zheng, 2009; Kodama et al., 2011, 2012).

Mottled mice appear to be a good model for exploring possible new therapeutic strategies of $\mathrm{Cu}$ administration in patients with Menkes disease. Cu-treatment applied as intraperitoneal or subcutaneous injections before the 7 th day of postnatal life have been shown to improve the viability of mosaic (Kowal et al., 2010; Lenartowicz et al., 2010), brindled (Phillips et al., 1986) and macular mutant males (Shiraishi et al., 1988). Cu-treated mosaic mutant males survive significantly longer, achieve maturity and do not manifest neurological problems. Nevertheless, they still display a defect in pigmentation, and are usually smaller than control males (Lenartowicz et al., 2010). In both humans and mice, the $\mathrm{BBB}$ is immature during the first days after birth, and $\mathrm{Cu}$ can be pumped to the brain despite the lack of ATP7A activity. This is a critical period for initiating successful therapy 
(Kodama et al., 2011, 2012). In mice, if therapy starts later than day 10, almost all mutants die (Mercer et al., 1999).

Therapy in Menkes disease is mainly focused on $\mathrm{Cu}$ delivery to the CNS. A new and effective treatment consists of a "combined therapy", in which $\mathrm{Cu}$ is administered together with lipophilic $\mathrm{Cu}$ chelators such as diethyldithiocarbamate (DEDTC) or dimethyldithiocarbamate (DMDTC). It is noteworthy that $\mathrm{Cu}$ in a lipid-soluble complex with DMDTC or DEDTC has a high capacity to penetrates the BBB (Tanaka et al., 1990; Kodama et al., 2005). Experiments performed on macular mice subjected to $\mathrm{CuCl}_{2}$ therapy on postnatal day 7 followed by combined $\mathrm{CuCl}_{2}$ and DMDTC therapy started at postnatal day 28 , indicated that the combined treatment leads to a significant increase in the amount of $\mathrm{Cu}$ in the brain, and the treated mice survive longer than untreated ones (Tanaka et al., 1990; Kodama et al., 2005). We have also obtained very promising results by giving mosaic mice a $\mathrm{CuCl}_{2}$-DMDTC combined treatment prenatally starting on day 7 of pregnancy. Mosaic mutant offspring of females that underwent the combined $\mathrm{CuCl}_{2}$-DMDTC treatment show increased $\mathrm{Cu}$ level in the brain; this effect persists at least into the 2nd week of postnatal life. Furthermore, prenatal treatment with $\mathrm{Cu}$ compounds in mosaic mice lead to an increase in survival, improved locomotion performance, and a higher body mass (Lenartowicz et al., 2012b). Similar results were obtained in macular mice treated with $\mathrm{Cu}$ injections and oral disulfirm from postnatal day 7 (Bhadhprasit et al., 2012). Disulfirm is a dimer of DEDTC used for treating alcoholism and cocaine addiction (Bhadhprasit et al., 2012).

The activity of cytochrome c oxidase is higher in the brain of the Cu-DEDTC treated macular mutants when compared to the mutants treated with $\mathrm{CuCl}_{2}$ alone. Analysis of the catecholamine levels in the brain of the treated mice indicate that the dopamine levels are lower and the levels of noradrenaline and adrenaline are higher when compared to untreated mice, indicating that the $\mathrm{DBH}$ activity had improved with the treatment (Kodama et al., 2005). These findings suggest that DEDTC improves the transport of $\mathrm{Cu}$ to neurons in the brains of mottled mice making $\mathrm{Cu}$ available to $\mathrm{Cu}$-dependent enzymes (Kodama et al., 2005).

Moreover, we and others have observed that the combined therapy efficiently reduces $\mathrm{Cu}$ accumulation in the kidney of treated mottled mice (Phillips et al., 1991; Tanaka et al., 1990; Kodama et al., 1993; Lenartowicz et al., 2012b), which might be a very important effect, considering the accumulation of $\mathrm{Cu}$ in the kidney of mottled mice and Menkes patients as a result of $\mathrm{Cu}$ treatment (Phillips et al., 1991; Kodama et al., 1993; Zaffanello et al., 2006; Kaler et al., 2008). Cu accumulation in the kidney induces a strong nephrotoxic effect (Lenartowicz et al., 2002, 2010).

Interestingly, reduced $\mathrm{Cu}$ accumulation in the kidney has also been achieved using the highly lipophilic organic $\mathrm{Cu}$ complex, Cu-pyruvaldehyde bis $\left(\mathrm{N}^{4}\right.$-methylthiosemicarbazone; $\mathrm{Cu}-\mathrm{PTSM}$ ). In the cells, Cu-PTSM is irreversibly reduced and cleaved to liberate $\mathrm{Cu}$ ions which can be incorporated into the intracellular $\mathrm{Cu}$ pools (Fujibayashi et al., 1993; Munakata et al., 2012). In macular mutants treated with $\mathrm{Cu}-\mathrm{PTSM}$, the renal $\mathrm{Cu}$ content was half of the $\mathrm{Cu}$ content in $\mathrm{CuCl}_{2}$-treated mutants. However there were no significant differences in brain $\mathrm{Cu}$ levels between $\mathrm{CuCl}_{2}$ and $\mathrm{Cu}-\mathrm{PTSM}$ treated mutants, but cytochrome c oxidase activity was higher in Cu-PTSM treated macular mice (Munakata et al., 2012).

The next step in developing new effective treatments for Menkes disease was to study the possibilities of correcting the mutated ATP7A gene. Brindled mice served as an experimental model for the construction of transgenic mice that expressed the human ATP7A gene (Llanos et al., 2006; Donsante et al., 2011). Recombinant adeno-associated virus encoding a $\mathrm{N}$-terminal truncated form of ATP7A (containing two instead of six copper binding sites) was injected into the lateral cerebral ventricles of neonatal brindled mutants. Transgenic brindled mice survived significantly longer than untreated mice and were fertile. However, the coat color and the $\mathrm{Cu}$ concentration in the organs of the rescued mutants resembled those in heterozygous females (Llanos et al., 2006). These results confirm the high degree of homology between the mouse and human Atp7a/ATP7A genes because the human gene was able to correct a genetic defect in mutant mice. Moreover, mutants treated with $\mathrm{CuCl}_{2}$ in combination with gene therapy survived even longer and the $\mathrm{Cu}$ level and activity of $\mathrm{DBH}$ in the brain was significantly increased, resulting in the improvement of neuromuscular strength and balance (Donsante et al., 2011).

\section{INTERACTION BETWEEN CU AND IRON: LESSONS FROM MOUSE MODELS OF MENKES DISEASES}

The systemic iron homeostasis is maintained by the coordinated regulation of iron absorption in the duodenum, iron recycling of senescent erythrocytes in macrophages, and mobilization of iron stored in the liver. These processes are controlled by hepcidin, a key iron-regulatory hormone synthesized mainly in hepatocytes in response to iron stores, erythropoiesis, hypoxia and inflammation (Viatte and Vaulont, 2009). Hepcidin acts by posttranslational downregulating of ferroportin (Fpn), the only known iron exporter. The loss of Fpn decreases the iron flow into plasma from absorptive enterocytes, macrophages, and hepatocytes, thereby lowering plasma iron concentrations, contributing to intracellular iron arrest and thus leading to functional anemia. Apart from the degradation of Fpn triggered by hepcidin, multiple regulatory mechanisms control the amount of cell surface Fpn expression in tissue macrophages and absorptive enterocytes (Beaumont, 2010).

Some pathways of iron homeostasis largely depend on the activity of $\mathrm{Cu}$-containing ferroxidases, such as ceruloplasmin (Cp) and hephastin (Heph). The close relationship between the biology of $\mathrm{Cu}$ and iron in mammals has been recognized and has for many years mainly been focused on the role of $\mathrm{Cp}$ expressed in macrophages, in facilitating iron recycling from senescent red blood cells (Collins et al., 2010). In humans, this process recovers approximately $25 \mathrm{mg}$ iron per day, which corresponds to the daily requirement of iron for erythropoiesis. $\mathrm{Cp}$ is mainly synthesized in hepatocytes in the form of apo$\mathrm{Cp}$. Incorporation of $\mathrm{Cu}$ into apo-Cp results in the formation of the redox-active holoenzyme and is mediated by ATP7B during transit through the TGN. It has been shown that an 
alternative spliced glycosylphosphatidylinositol (GPI) variant of Cp (Cp-GPI) originally characterized in the brain (Patel and David, 1997) is of particular importance for iron metabolism (Collins et al., 2010; Prohaska, 2011). Cp-GPI cooperates with Fpn to facilitate the movement of iron out of cells. First, ferrous ions transported into the circulation by Fpn are oxidized by Cp-GPI and ferric ions are then bound by transferrin. Second, Cp-GPI is required for the stability of cell surface Fpn (De Domenico et al., 2007). The importance of Cp in human iron homeostasis has been confirmed by the description of the human congenital disease, aceruloplasminemia, in which mutations in the ceruloplasmin gene lead to its absence in plasma (Yoshida et al., 1995). While the anemia observed in humans with aceruloplasminemia is not severe, severe iron loading is found in the brain. Humans and mice suffering from aceruloplasminemia showed a striking impairment in the movement of iron out of reticuloendothelial cells and hepatocytes (Harris et al., 1995). It is not surprising therefore that iron-limited erythropoiesis is the main consequence of $\mathrm{Cu}$ deficiency. Metabolic pathways involving $\mathrm{Cu}$ and iron are also linked through the second $\mathrm{Cu}$ containing ferroxidase Heph, which is implicated in iron efflux from the intestine (Collins et al., 2010). Heph co-localizes with Fpn on the basolateral membrane of duodenal enterocytes, where it stimulates the absorption of dietary iron. The sla (sexlinked anemia) mice have a defect in the basolateral export of iron from intestinal enterocytes into the circulation due to mutation in the hephastin gene, resulting in iron deficiency and microcytic hypochromic anemia (Vulpe et al., 1999). Systemic iron deficiency has also been reported in $\mathrm{Cu}$-deficient mice that display decreased Heph ferroxidase activity in the intestine (Chen et al., 2006).

Mottled mice seem to be valuable for studying the interaction between $\mathrm{Cu}$ and iron metabolisms in vivo. Systemic iron homeostasis is mainly established and maintained by four cell types: intestinal enterocytes, reticuloendothelial macrophages, hepatocytes and progenitors of red blood cells. In this context, diverse tissue specific deregulated patterns of $\mathrm{Cu}$ content and distribution in mottled mice may increase our understanding of $\mathrm{Cu}$-iron interactions at different sites in the body where iron balance is controlled. Recently, brindled mice served for the first time as an animal model in which iron homeostasis was studied (Gulec and Collins, 2013). Specifically, this study referred to the $\mathrm{Cu}$-related compensatory response of the intestinal epithelium, the main site of iron entrance into the body in order to protect against iron deficiency. When brindled mice were deprived of iron, they developed anemia and enhanced intestinal iron absorption, similarly to wild-type mice. However, in contrast to controls, the upregulation of iron absorption in mutant mice was accompanied by increased enterocyte and hepatic $\mathrm{Cu}$ content as well as by increased serum ferroxidase (Cp) activity (Gulec and Collins, 2013). Additional mechanistic and molecular aspects of increased iron absorption in Atp7a mutants have been raised in rat intestinal epithelial cells (IEC-6), in which the Atp7a gene was silenced using short hairpin RNA technology. Transepithelial iron transport was increased in knockdown cells under both normal and iron-deficient conditions (Gulec and Collins, 2014). This phenomenon was associated with increased expressions of duodenal cytochrome b and Fpn involved in intestinal iron uptake and efflux, respectively (Gulec and Collins, 2014).

In our recent paper we used $\mathrm{Cu}$-deficient mosaic mutants to investigate metabolic connections between $\mathrm{Cu}$ and iron (Lenartowicz et al., 2014). Mosaic mutant hemizygous males normally die by day 17 of life (Lenartowicz et al., 2012a) from severe $\mathrm{Cu}$ deficiency; therefore we used 14-day-old animals for our study. The erythrocytes of these mutants are $\mathrm{Cu}$-deficient, display decreased activity/expression of the antioxidant enzyme SOD1, and have cell membrane abnormalities. SOD1 scavenges the superoxide anion, a reactive oxygen species contributing to the toxicity of iron via the Fenton reaction (Zelko et al., 2002). In consequence, the mosaic mice show evidence of hemolysis accompanied by haptoglobin-dependent elimination of hemoglobin $(\mathrm{Hb})$ from the circulation, as well as the induction of heme oxygenase 1 (HO1) in the liver and kidney. Moreover, the hepcidin-Fpn regulatory axis is strongly affected in mosaic mice i.e., mutants show increased hepcidin and decreased Fpn expressions in the liver (Figure 3). Our results show for the first time the molecular mechanism of the induction of hemolysis by $\mathrm{Cu}$ deficiency and demonstrate how suckling mice adapt their iron metabolism to hemolytic insult (Lenartowicz et al., 2014).

\section{OTHER ANIMAL MODELS OF MENKES DISEASE}

\section{Danio rerio and Drosophila melanogaster as Model Organisms of Menkes Disease}

Although mottled mice have been a well-established and characterized mammalian model of Menkes disease for many years, recently scientists developed new non-mammalian models for this disorder such as the zebrafish (Danio rerio) and the fruit fly (Drosophila melanogaster) models. Both species have served as experimental animals in biology for many years due to relatively inexpensive maintenance and relative easiness for genetic manipulation. These new models expand our understanding of $\mathrm{Cu}$ metabolism in the cell and suggest new therapeutic strategies in Menkes disease.

$\mathrm{Cu}$ as a biometal plays a significant role not only in the adult organism, but it is also crucial in early developmental stages of humans and mice. It is difficult to follow the pathology of $\mathrm{Cu}$ metabolism during development in mammals. However, taking these facts into consideration, it seems that ex vivo fertilization, high fertility rate and rapid development make zebrafish an ideal model for such research. Embryos of D. rerio developed ex utero are optically clear, and therefore many of the processes of interest to the developmental biologist are easily observable. What is more, the genome of zebrafish has been sequenced and reveals that many genes and metabolic pathways are highly conserved between humans and zebrafish (Phillips and Westerfield, 2014).

Danio rerio absorbs $\mathrm{Cu}$ in two ways: via the intestine similarly to what is observed in mammals, and by the gills. Interestingly, the highest expression of the major $\mathrm{Cu}$ importer $\mathrm{Ctr} 1$ protein was detected in gut (Leung et al., 2014). Furthermore, the expression of Atp7a mRNA is ubiquitous in the zebrafish embryo and starts early in development (Mendelsohn et al., 2006). Besides 


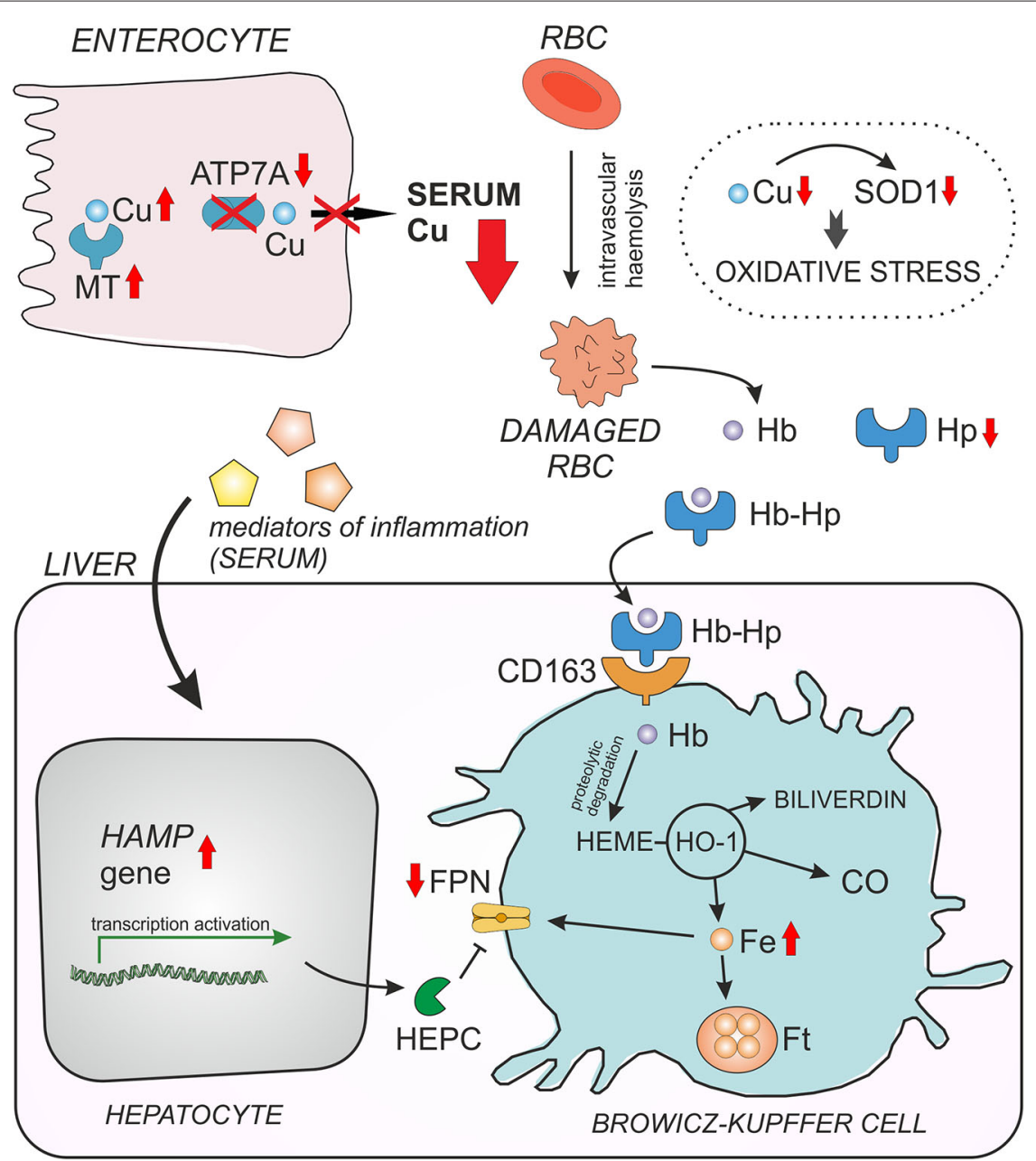

FIGURE 3 | Interaction between copper (Cu) and iron (Fe) in young mosaic mice. Duodenal enterocytes can export copper across the basolateral membrane by ATP7A protein. Due to ATP7A gene mutation in mosaic mice, copper cannot be released to the serum and accumulates within the enterocytes in a complex with metallothionein (MT). Decreased serum Cu level entails Cu deficiency in red blood cells (RBC) and in consequence reduced activity/expression of Cu, Zn-superoxide dismutase (SOD1), which play a crucial role in RBC antioxidant defense. As the result, Cu-deficient RBC of mosaic mice display morphological abnormalities and undergo intravascular hemeolysis connected with hemoglobin $(\mathrm{Hb})$ release to the serum and haptoglobin-dependent $(\mathrm{Hp})$ elimination of free $\mathrm{Hb}$ from the circulation. When $\mathrm{Hb}$ is released from damaged RBC, it is instantly bound by haptoglobin ( $\mathrm{Hp}$ ) and forms a Hp-Hb high-affinity complex. This complex is then rapidly taken up from the circulation by the CD163 receptor present mainly on tissue macrophages (in the liver on Browicz-Kupffer cells). The CD163 receptor has no measurable affinity for free $\mathrm{Hp}$. Thus, specific recognition of $\mathrm{Hp}-\mathrm{Hb}$ by $\mathrm{CD} 163$ explains the decrease in $\mathrm{Hp}$ concentration in the serum during accelerated hemeolysis. The proteolytic $\mathrm{Hb}$ degradation in Browicz-Kupffer cells leads to the release of heme, which is then enzymatically decomposed by heme oxygenase 1 ( $\mathrm{HO}-1)$ resulting in the formation of carbon monoxide (CO), biliverdin and Fe. Non-heme iron can be then stored as a complex with ferritin (Ft) or exported outside the cell by ferroportin (FPN), the sole cellular exporter of ionic iron known in mammalian cells. The content of hepatic non-heme Fe is elevated in mosaic mice, probably due to decreased expression of FPN. The concentration of cell surface Fpn largely depends on the post-translational regulation through internalization and degradation following hepcidin (Hepc) binding. Down-regulation of FPN expression in the liver of young mosaic mice is probably due to the concomitant up-regulation of hepatic hepcidin gene (Hamp), synthesized mainly in hepatocytes in response to systemic inflammation reported to occur in mosaic mice.

it is believed that the Atp7a pump is necessary for loading maternal $\mathrm{Cu}$ into the egg (Madsen and Gitlin, 2008). Experiments have also shown that during embryogenesis Atp7a is responsible for proper $\mathrm{Cu}$ metabolism in individual cells. However Atp7a may not be essential for $\mathrm{Cu}$ transport from the yolk sac or within the embryo (Mendelsohn et al., 2006). In adult zebrafish, the expression pattern of Atp7a is similar to that found in mammalian tissues, such as intestine, kidney, heart, gills and liver (Chen and Chan, 2011; Leung et al., 2014). Atp7a is expressed most abundantly in the kidneys under elevated $\mathrm{Cu}$ level as well as under control conditions which suggests a major role of Atp7a in $\mathrm{Cu}$ export in D. rerio similar to observations in mice (Leung et al., 2014). However, in contrast to mice, in which Atp7a plays a significant role as a transporter in the brain barrier systems, glial cells and neurons (Lutsenko et al., 2010; Zheng and Monnot, 2012), the expression of Atp7a in the brain of $D$. rerio is very low (Chen and Chan, 2011). Surprisingly, in the liver of zebrafish the expression level of 
the Atp7a gene is high compared to the expression level of Atp7b (Leung et al., 2014), whereas the major Cu-ATPase in the adult mammalian liver is in fact $A t p 7 b$ (Lutsenko et al., 2007). The Atp7a/ATP7A proteins in D. rerio and mammals play similar roles, and knockdown of the Atp7a gene (Mendelsohn et al., 2006; Madsen et al., 2008) as well as its inhibition by antisense oligonucleotide (Chen et al., 2011) result in a lack of pigmentation and the notochord deformation phenotype in embryos. These phenotypic effects are probably correlated to the dysfunction of $\mathrm{Cu}$-dependent enzymes, i.e., tyrosinase and lysyl oxidase (Mendelsohn et al., 2006). These phenotypic effects are similar to what is observed in mottled mice (Kim and Petris, 2007) as well as in Menkes disease patients (Tümer and Møller, 2010). Moreover, expression of the human ATP7A gene in Atp7a zebrafish mutants can restore the normal phenotype (Mendelsohn et al., 2006). These data also confirm a high degree of conservation of $\mathrm{Cu}$ metabolism pathways between mammals and fish.

Since 2006, in Gitlin's laboratory, three calamity mutants of zebrafish: cal ${ }^{\text {vu69 }}$ (Mendelsohn et al., 2006), calgw246 (Madsen et al., 2008) and cal ${ }^{g w 71}$ (Madsen and Gitlin, 2008), have been described as novel vertebrate models of Menkes disease. These strains were generated by $\mathrm{N}$-ethyl-N-nitrosourea mutagenesis, and mutations in the Atp7a gene were confirmed by sequencing. Although these mutations are different, the phenotype effects are similar regarding the presence of notochord defects and the lack of pigmentation.

The mildest mutation, calgw71 results in a single, nonconservative amino acid substitution (p.Ile1061Ser) in the region close to the critical ATP binding residue (Glu1064) of the Atp7a protein. This single amino acid substitution results in significant depletion of functional protein in embryos. This calgw71 variant was, when expressed in fibroblasts obtained from patients with Menkes disease, able to deliver a suitable amount of $\mathrm{Cu}$ to the human $\mathrm{Cu}$-dependent enzyme-tyrosinase. However, under $\mathrm{Cu}$-depleted conditions, the activity of tyrosinase was reduced when compared to complementation with wild-type construct. Probably the mutated form of Atp7a retains some transport activity (Madsen and Gitlin, 2008). These data suggest that even low activity of Atp7a protein is sufficient to maintain an almost normal phenotype similarly to what we observed in humans (Møller et al., 2000; Skjørringe et al., 2011). Because the cal ${ }^{g w 71}$ animals are viable, it was possible to examine several postembryonic effects of this mutation. Surprisingly, under adequate $\mathrm{Cu}$ conditions, adult homozygous mutants of zebrafish did not display a mutant phenotype, but in the absence of $\mathrm{Cu}$, vertebral skeletal defects in larva were evident during development. What is more, treatment of larva with the chelator neocuproine (added to the water) leads to death, which indicates an increase in sensitivity to mild $\mathrm{Cu}$ deprivation as the embryo develops (Madsen and Gitlin, 2008).

Gitlin's group has demonstrated the usefulness of morpholinos designed for targeting sequences near the mutant splice sites in order to force correct splicing and thereby correct aberrant splicing in an embryonic zebrafish (Madsen et al., 2008). Morpholinos which are oligonuclotides, usually 25 bases in length, are designed to target the RNA sequence of interest via complementary base pairing. The oligonuclotides bind to a target sequence thereby facilitating steric hindrance of proper transcript processing or translation (Bill et al., 2009). Injections of morpholino into calamity mutants fully rescue the $\mathrm{Cu}$-deficient phenotype through the production of normal wildtype Atp7a. Morpholino oligonuclotides lead to a restoration of wild-type protein without detectable changes in the mRNA, suggesting a competitive translational regulation (Madsen et al., 2008).

Drosophila melanogaster has for several decades been one of the most powerful in vivo genetic model organisms used to describe molecular mechanisms of many biological pathways. What is more, the simplicity of its nervous system has made this small insect an especially valuable model in neurobiology. Thus, the fruit fly has contributed to the identification of genes and proteins underlying "molecular machinery" in the brain of processes, such as learning, memory formation, sleep or circadian rhythms. Moreover, since the nucleotide sequence of D. melanogaster genome has been published, it is presumed that approximately $10 \%$ of the genes common in both human and fly are involved in neurological diseases (Greenspan and Dierick, 2004). Therefore, D. melanogaster has also been used as a model for neurodegenerative diseases, like Huntington's disease, Parkinson's disease, Alzheimer's disease and most recently Menkes disease.

Research into $\mathrm{Cu}$ metabolism in Drosophila began over 50 years ago. However, during the last decade scientists have particularly focused on the identification of regulatory mechanisms for cellular $\mathrm{Cu}$ metabolism. It has been proved that orthologs of the major eukaryotic $\mathrm{Cu}$ regulatory genes are well conserved between mammals and insects. $\mathrm{Cu}$ transporters and chaperons as well as a Cu-ATPase have been identified in the fruit fly (Norgate et al., 2007; Kirby et al., 2008; Hua et al., 2011). In contrast to mammals, D. melanogaster carries only one Cu-transporting ATPase known as DmATP7. The similarity between human ATP7A and ATP7B proteins is roughly $60 \%$. Nevertheless, motifs responsible for basolateral targeting and retention of ATP7A are conserved in DmATP7, whereas targeting motifs in ATP7B are not (Southon et al., 2010). Similarly to human Cu-ATPases, DmATP7 is expressed from early embryogenesis. In adult D. melanogaster DmATP7 is expressed at high levels in the digestive tract and the nervous system (Norgate et al., 2006; Burke et al., 2008). DmATP7 seems to play the same role as the mammalian orthologs and is essential for $\mathrm{Cu}$ efflux in several D. melanogaster tissues (Southon et al., 2004; Burke et al., 2008). Furthermore, high conservation of $\mathrm{Cu}$ ATPases between mammals and fruit fly permits the correction of the $\mathrm{Cu}$ hyper-accumulation phenotype of cultured fibroblasts from a Menkes disease patient carrying a null ATP7A mutation, by the expression of DmATP7 (Southon et al., 2010). In the fruit fly, the inhibition of DmATP7 expression in peptidergic neurons shows that neuropeptide amidation is perturbed (Sellami et al., 2012), and resemble that seen in the brindled mice, in which PAM is impaired (Steveson et al., 2003; Niciu et al., 2007).

Norgate et al. (2006) established a classical D. melanogaster model of Menkes disease with a null mutation. This mutant seems extremely lethargic, which could be explained by the 
dysfunction of the $\mathrm{Cu}$-dependent nervous system or respiratory system. The mouth parts of the DmATP7 ${ }^{-/-}$larva are smaller and reduced in pigmentation compared to controls. Moreover $D m A T P 7^{-/}$cell clones generated in control flies in the thorax and abdomen are depigmented. These observations indicate that DmATP7 supplies Cu to tyrosinase in D. melanogaster (Norgate et al., 2006) similarly to zebrafish (Mendelsohn et al., 2006; Madsen et al., 2008), mouse and humans (Petris et al., 2000). Unfortunately, DmATP7 ${ }^{-/-}$insects are unable to grow after hatching and die early in development making it impossible to examine adult mutants (Norgate et al., 2006).

To overcome this problem, most recently Bahadorani et al. (2010) constructed a new Drosophila model of Menkes disease by conditional silencing of DIATP7 only in the digestive tract. Expression of a RNAi construct against DmATP7 was limited to gut cells. As is the case in Menkes patients and mottled mice, inhibiting the expression of DMATP7 in the intestine enhanced lethality. It is hypothesized that the lethality of insects is the result of reduced $\mathrm{Cu}$ level in the nervous system. This hypothesis has been proposed on the basis of observations showing that the brains of the model flies were smaller and contained less stainable material when compared to control flies. Interestingly, roughly $50 \%$ of the flies survived to adulthood. However, in contrast to the mottled mice, such flies exhibit normal morphology without hypopigmentation or abnormalities of bristle hair-like structures. The surviving adults can be compared to OHS patients. The life span of such flies was only slightly shorter than that of control flies. Such adult survivors were sensitized to the oxidative stress of hyperoxia probably because of the reduced activity of SOD1 (Bahadorani et al., 2010). Reduction of SOD1 is also observed in the brain of Menkes disease patients (Shibata et al., 1995), mutant mice and D. rerio (Chen et al., 2011; Lenartowicz et al., 2014).

Studies on Drosophila Menkes disease model revealed MTF-1 as a potential therapeutic factor. The expression of MTF-1 in gut-DmATP7-RNAi larva enhances their survival to adulthood. A defensive mechanism probably involves the induction of methallothioneines, which bind excess $\mathrm{Cu}$ accumulated in the gut and prevent its toxic effect. The second scenario explains the therapeutic effect by the induction of the $\mathrm{Cu}$ importer $(\mathrm{Ctr} 1 \mathrm{~B})$ expression, and thus the transfer of additional $\mathrm{Cu}$ to the tissues (Bahadorani et al., 2010).

\section{REFERENCES}

Arredondo, M., Muñoz, P., Mura, C. V., and Nùñez, M. T. (2003). DMT1, a physiologically relevant apical Cu1+ transporter of intestinal cells. Am. J. Physiol. Cell Physiol. 284, C1525-C1530. doi: 10.1152/ajpcell.00480.2002

Bahadorani, S., Bahadorani, P., Marcon, E., Walker, D. W., and Hilliker, A. J. (2010). A Drosophila model of Menkes disease reveals a role for DmATP7 in copper absorption and neurodevelopment. Dis. Model. Mech. 3, 84-91. doi: 10. 1242/dmm.002642

Bahi-Buisson, N., Kaminska, A., Nabbout, R., Barnerias, C., Desguerre, I., De Lonlay, P., et al. (2006). Epilepsy in Menkes disease: analysis of clinical stages. Epilepsia 47, 380-386. doi: 10.1111/j.1528-1167.2006.00432.x

Barry, A. N., Shinde, U., and Lutsenko, S. (2010). Structural organization of human $\mathrm{Cu}$-transporting ATPases: learning from building blocks. J. Biol. Inorg. Chem. 15, 47-59. doi: 10.1007/s00775-009-0595-4

\section{CONCLUDING REMARKS}

To summarize, while murine models of Menkes disease are well-established, non-mammalian models can be used in experiments which are technically difficult to carry out in mammals. The rapid external development of the transparent zebrafish embryo permits a characterization of developmental abnormalities and allows cellular and genetic manipulations that are not possible during in utero development. The models can be used for large-scale screening for compounds that regulate $\mathrm{Cu}$ metabolism and could be potential drugs for Menkes disease treatment. The animals $D$. rerio and $D$. melanogaster are also invaluable to the development of new therapeutic strategies utilizing synthetic oligonucleotide analogs or the therapeutic effect of the MTF-1 protein.

\section{AUTHOR CONTRIBUTIONS}

ML, WK, PL and OP were drafting the work and substantial contributions to the conception and design of the work. PG, RS were revising manuscript critically for important intellectual content. LBM was revising manuscript critically for important intellectual content and design of the work.

\section{FUNDING}

This work was supported by grant no. 2012/05/B/NZ4/02423 from the National Science Center of Poland.

\section{ACKNOWLEDGMENTS}

We thank Aneta Jończy for help with designing and making the scheme of copper-iron interactions in mosaic mice and Susan Peters for proofreading the manuscript.

\section{SUPPLEMENTARY MATERIAL}

The Supplementary Material for this article can be found online at: http://journal.frontiersin.org/article/10.3389/fnmol. 2015.00072/abstract

Beaumont, C. (2010). Multiple regulatory mechanisms act in concert to control ferroportin expression and heme iron recycling by macrophages. Haematologica 95, 1233-1236. doi: 10.3324/hemeatol.2010. 025585

Bhadhprasit, W., Kodama, H., Fujisawa, C., Hiroki, T., and Ogawa, E. (2012). Effect of copper and disulfiram combination therapy on the macular mouse, a model of Menkes disease. J. Trace Elem. Med. Biol. 26, 105-108. doi: 10.1016/j. jtemb.2012.05.002

Bill, B. R., Petzold, A. M., Clark, K. J., Schimmenti, L. A., and Ekker, S. C. (2009). A primer for morpholino use in zebrafish. Zebrafish 6, 69-77. doi: 10.1089/zeb. 2008.0555

Bousquet-Moore, D., Mains, R. E., and Eipper, B. A. (2010). Peptidylgycine $\alpha$ amidating monooxygenase and copper: a gene-nutrient interaction critical to nervous system function. J. Neurosci. Res. 88, 2535-2545. doi: 10.1002/jnr. 22404 
Burke, R., Commons, E., and Camakaris, J. (2008). Expression and localization of the essential copper transporter DmATP7 in Drosophila neuronal and intestinal tissues. Int. J. Biochem. Cell Biol. 40, 1850-1860. doi: 10.1016/j.biocel. 2008.01.021

Camakaris, J., Mann, J. R., and Danks, D. M. (1979). Copper metabolism in mottled mouse mutants: copper concentrations in tissues during development. Biochem. J. 180, 597-604. doi: 10.1042/bj1800597

Cecchi, C., and Avner, P. (1996). Genomic organization of the mottled gene, the mouse homolog of the human Menkes disease gene. Genomics 37, 96-104. doi: 10.1006/geno.1996.0525

Cecchi, C., Bissotto, M., Tosi, M., and Avner, P. (1997). The mottled mouse as a model for human Menkes disease: identification of mutations in the Atp7a gene. Hum. Mol. Genet. 6, 425-433. doi: 10.1093/hmg/6. 3.425

Chen, D. S., and Chan, K. M. (2011). PCR-cloning of tilapia ATP7A cDNA and its mRNA levels in tissues of tilapia following copper administrations. Aquat. Toxicol. 105, 717-727. doi: 10.1016/j.aquatox.2011.09.011

Chen, H., Huang, G., Su, T., Gao, H., Attieh, Z. K., McKie, A. T., et al. (2006). Decreased hephaestin activity in the intestine of copper-deficient mice causes systemic iron deficiency. J. Nutr. 136, 1236-1241.

Chen, H. R., Yang, H. C., Hsieh, D. J. Y., Liu, Z., and Tsai, K. J. (2011). Zebrafish sod1 and sp1 expression are modulated by the copper ATPase gene atp7a in response to intracellular copper status. Chem. Biol. Interact. 189, 192-197. doi: 10.1016/j.cbi.2010.12.003

Choi, B. S., and Zheng, W. (2009). Copper transport to the brain by the bloodbrain barrier and blood CSF barrier. Brain Res. 1248, 14-21. doi: 10.1016/j. brainres.2008.10.056

Christodoulou, J., Danks, D. M., Sarkar, B., Baerlocher, K. E., Casey, R., Horn, N., et al. (1998). Early treatment of Menkes disease with parenteral copperhistidine: long-term follow-up of four treated patients. Am. J. Med. Genet. 76, 154-164. doi: 10.1002/(sici)1096-8628(19980305)76:2<154::aid-ajmg9>3. $0 . \mathrm{co} ; 2-\mathrm{t}$

Collins, J. F., and Klevay, L. M. (2011). Copper. Adv. Nutr. 2, 520-522. doi: 10. 3945/an.111.001222

Collins, J. F., Prohaska, J. R., and Knutson, M. (2010). Metabolic crossroads of iron and copper. Nutr. Rev. 68, 133-147. doi: 10.1111/j.1753-4887.2010. 00271.x

Cunliffe, P., Reed, V., and Boyd, Y. (2001). Intragenic deletions at Atp7a in mouse models for Menkes disease. Genomics 74, 155-162. doi: 10.1006/geno.2001. 6529

Das, S., Levinson, B., Vulpe, C., Whitney, S., Gitschier, J., and Packman, S. (1995). Similar splicing mutations of the Menkes/mottled copper-transporting ATPase gene in occipital horn syndrome and the blotchy mouse. Am. J. Hum. Genet. 56, 570-576.

De Domenico, I., Ward, D. M., di Patti, M. C., Jeong, S. Y., David, S., Musci, G., et al. (2007). Ferroxidase activity is required for the stability of cell surface ferroportin in cells expressing GPI-ceruloplasmin. EMBO J. 26, 2823-2831. doi: 10.1038/sj.emboj.7601735

Donsante, A., Johnson, P., Jansen, L. A., and Kaler, S. G. (2010). Somatic mosaicism inMenkes disease suggests choroid plexus-mediated copper transport to the developingbrain. Am. J. Med. Genet. A 152, 2529-2534. doi: 10. 1002/ajmg.a.33632

Donsante, A., Sullivan, P., Goldstein, D. S., Brinster, L. R., and Kaler, S. G. (2013). L-threo-dihydroxyphenylserine corrects neurochemical abnormalities in a Menkes disease mouse model. Ann. Neurol. 73, 259-265. doi: 10.1002/ana. 23787

Donsante, A., Yi, L., Zerfas, P. M., Brinster, L. R., Sullivan, P., Goldstein, D. S., et al. (2011). ATP7A gene addition to the choroid plexus results in long-term rescue of the lethal copper transport defect in a Menkes disease mouse model. Mol. Ther. 19, 2114-2123. doi: 10.1038/mt.2011.143

Eipper, B. A., Milgram, S. L., Husten, E. J., Yun, H. Y., and Mains, R. E. (1993). Peptidylglycine alpha-amidating monooxygenase: a multifunctional protein with catalytic, processing and routing domains. Protein Sci. 2, 489-497. doi: 10. 1002/pro.5560020401

Eipper, B. A., Stoffers, D. A., and Mains, R. E. (1992). The biosynthesis of neuropeptides: peptide alpha-amidation. Annu. Rev. Neurosci. 15, 57-85. doi: 10.1146/annurev.neuro.15.1.57

El Meskini, R., Cline, L. B., Eipper, B. A., and Ronnett, G. V. (2005). The developmentally regulated expression of Menkes protein ATP7A suggests a role in axon extension and synaptogenesis. Dev. Neurosci. 27, 333-348. doi: 10. $1159 / 000086713$

Fraser, A. S., Nay, T., and Turner, H. N. (1953). Growth of the mouse coat. II. Effect of sex and pregnancy. Aust. J. Biol. Sci. 6, 645-656.

Fujibayashi, Y., Wada, K., Taniuchi, H., Yonekura, Y., Konishi, J., and Yokoyama, A. (1993). Mitochondria-selective reduction of 62Cu-pyruvaldehyde bis(N4methylthiosemicarbazone) (62Cu-PTSM) in the murine brain; a novel radiopharmaceutical for brain positron emission tomography (PET) imaging. Biol. Pharm. Bull. 16, 146-149. doi: 10.1248/bpb.16.146

Gaier, E. D., Eipper, B. A., and Mains, R. E. (2013a). Copper signaling in the mammalian nervous system: synaptic effects. J. Neurosci. Res. 91, 2-19. doi: 10 1002/jnr.23143

Gaier, E. D., Miller, M. B., Ralle, M., Aryal, D., Wetsel, W. C., Mains, R. E., et al. (2013b). Peptidylglycine $\alpha$-amidating monooxygenase heterozygosity alters brain copper handling with region specificity. J. Neurochem. 127, 605-619. doi: $10.1111 /$ jnc. 12438

Godwin, S. C., Shawker, T., Chang, B., and Kaler, S. G. (2006). Brachial artery aneurysms in Menkes disease. J. Pediatr. 149, 412-415. doi: 10.1016/j.jpeds. 2006.05.041

Gourdon, P., Liu, X. Y., Skjørringe, T., Morth, J. P., Møller, L. B., Pedersen, B. P., et al. (2011). Crystal structure of a copper-transporting PIB-type ATPase. Nature 29, 59-64. doi: 10.1038/nature10191

Green, M. C. (1981). "Catalog of mutant genes and polymorphic loci," in Genetic Variants and Strains of the Laboratory Mouse, eds M. F. Lyon and A. G. Searle (Oxford: Oxford University Press), 162-166.

Greenspan, R. J., and Dierick, H. (2004). 'Am not I a fly like thee?' From genes in fruit flies to behavior in humans. Hum. Mol. Genet. 13, R267-R273. doi: 10. 1093/hmg/ddh248

Grimes, A., Hearn, C. J., Lockhart, P., Newgreen, D. F., and Mercer, J. F. (1997) Molecular basis of the brindled mouse mutant $(\mathrm{Mo}(\mathrm{br}))$ : a murine model of Menkes disease. Hum. Mol. Genet. 6, 1037-1042. doi: 10.1093/hmg/6.7.1037

Grüneberg, H. (1969). Threshold phenomena versus cell heredity in the manifestation of sex-linked genes in mammals. J. Embryol. Exp. Morphol. 22, 145-179.

Gulec, S., and Collins, J. F. (2013). Investigation of iron metabolism in mice expressing a mutant Menke's copper transporting ATPase (Atp7a) protein with diminished activity (Brindled; $\mathrm{Mo}^{\mathrm{Br} / y}$ ). PLoS One 8:e66010. doi: 10 . 1371/journal.pone.0066010

Gulec, S., and Collins, J. F. (2014). Silencing the Menkes copper-transporting ATPase (Atp7a) gene in rat intestinal epithelial (IEC-6) cells increases iron flux via transcriptional induction of ferroportin 1 (Fpn1). J. Nutr. 144, 12-19. doi: $10.3945 /$ jn.113.183160

Haddad, M. R., Patel, K. D., Sullivan, P. H., Goldstein, D. S., Murphy, K. M., Centeno, J. A., et al. (2014). Molecular and biochemical characterization of mottled-dappled, an embryonic lethal Menkes disease mouse model. Mol. Genet. Metab. 113, 294-300. doi: 10.1016/j.ymgme.2014.10.001

Hardman, B., Manuelpillai, U., Wallace, E. M., van der Wasenburg, S., Carter, M., Mercer, J. F., et al. (2004). Expression and localization of Menkes and Wilson copper transporting ATPases in human placenta. Placenta 25, 512-517. doi: 10. 1016/j.placenta.2003.11.013

Hardman, B., Michalczyk, A., Greenough, M., Camakaris, J., Mercer, J., and Ackland, L. (2007). Distinct functional roles for the Menkes and Wilson copper translocating P-type ATPases in human placental cells. Cell. Physiol. Biochem. 20, 1073-1084. doi: 10.1159/000110718

Harris, Z. L., Takahashi, Y., Miyajima, H., Serizawa, M., MacGillivray, R. T., and Gitlin, J. D. (1995). Aceruloplasminemia: molecular characterization of this disorder of iron metabolism. Proc. Natl. Acad. Sci. U S A 28, 2539-2543. doi: 10. 1073/pnas.92.7.2539

Hodgkinson, V. L., Dale, J. M., Garcia, M. L., Weisman, G. A., Lee, J., Gitlin, J. D., et al. (2015). X-linked spinal muscular atrophy in mice caused by autonomous loss of ATP7A in the motor neuron. J. Pathol. 236, 241-250. doi: 10.1002/path. 4511

Hua, H., Günther, V., Georgiev, O., and Schaffner, W. (2011). Distorted copper homeostasis with decreased sensitivity to cisplatin upon chaperone Atox deletion in Drosophila. Biometals 24, 445-453. doi: 10.1007/s10534-011-9438-1

Hunt, D. M. (1974). Primary defect in copper transport underlies mottled mutants in the mouse. Nature 249, 852-854. doi: 10.1038/249852a0

Iwase, T., Nishimura, M., Sigimura, H., Igarashi, H., Ozawa, F., Shinmura, K., et al. (1996). Localization of Menkes gene expression in the mouse brain; 
its association with neurological manifestation in Menkes model mice. Acta Neuropathol. 91, 482-488. doi: 10.1007/s004010050455

Kaler, S. G. (1998). Metabolic and molecular bases of Menkes disease and occipital horn syndrome. Pediatr. Dev. Pathol. 1, 85-98. doi: 10.1007/s100249900011

Kaler, S. G. (2011). ATP7A-related copper transport diseases-emerging concepts and future trends. Nat. Rev. Neurol. 7, 15-29. doi: 10.1038/nrneurol.2010.180

Kaler, S. G., Buist, N. R. M., Holmes, C. S., Goldstein, D. S., Miller, R. C., and Gahl, W. A. (1995). Early copper therapy in classic Menkes disease patients with a novel splicing mutation. Ann. Neurol. 38, 921-928. doi: 10.1002/ana.410380613

Kaler, S. G., Holmes, C. S., Goldstein, D. S., Tang, J., Godwin, S. C., Donsante, A., et al. (2008). Neonatal diagnosis and treatment of Menkes disease. N. Engl. J. Med. 358, 605-614. doi: 10.1056/NEJMoa070613

Kaler, S. G., Liew, C. J., Donsante, A., Hicks, J. D., Sato, S., and Greenfield, J. C. (2010). Molecular correlates of epilepsy in early diagnosed and treated Menkes disease. J. Inherit. Metab. Dis. 33, 583-589. doi: 10.1007/s10545-010-9118-2

Kasama, T., and Tanaka, H. (1989). Effects of oral copper administration to pregnant heterozygous brindled mice on faetal viability and copper levels. $J$. Nutr. Sci. Vitaminol. (Tokyo) 35, 627-638. doi: 10.3177/jnsv.35.627

Kemppainen, R., Hämäläinen, E. R., Kuivaniemi, H., Tromp, G., Pihlajaniemi, T., and Kivirikko, K. I. (1996). Expression of mRNAs for lysyl oxidase and type III procollagen in cultured fibroblasts from patients with the Menkes and occipital horn syndromes as determined by quantitative polymerase chain reaction. Arch. Biochem. Biophys. 328, 101-106. doi: 10.1006/abbi.1996.0148

Kennerson, M. L., Nicholson, G. A., Kaler, S. G., Kowalski, B., Mercer, J. F., Tang, J., et al. (2010). Missense mutations in the copper transporter gene ATP7A cause X-linked distal hereditary motor neuropathy. Am. J. Hum. Genet. 86, 343-352. doi: 10.1016/j.ajhg.2010.01.027

Kim, B. E., and Petris, M. J. (2007). Phenotypic diversity of Menkes disease in mottled mice is associated with defects in localization and trafficking of the ATP7A protein. J. Med. Genet. 44, 641-646. doi: 10.1136/jmg.2007.049627

Kirby, J. B., Danks, D. M., Legge, G. J. F., and Mercer, J. F. B. (1998). Analysis of the distribution of $\mathrm{Cu}, \mathrm{Fe}$ and $\mathrm{Zn}$ and other elements in brindled mouse kidney using a scanning proton microprobe. J. Inorg. Biochem. 71, 189-197. doi: 10. 1016/s0162-0134(98)10053-3

Kirby, K., Jensen, L. T., Binnington, J., Hilliker, A. J., Ulloa, J., Culotta, V. C., et al. (2008). Instability of superoxide dismutase 1 of Drosophila in mutants deficient for its cognate copper chaperone. J. Biol. Chem. 283, 35393-35401. doi: 10.1074/jbc.m807131200

Kodama, H. (1993). Recent developments in Menkes disease. J. Inherit. Metab. Dis. 16, 791-799. doi: 10.1007/bf00711911

Kodama, H., Abe, T., Takama, M., Takahashi, I., Kodama, M., and Nishimura, M. (1993). Histochemical localization of copper in the intestine and kidney of macular mice: light and electron microscopic study. J. Histochem. Cytochem. 41, 1529-1535. doi: 10.1177/41.10.8245411

Kodama, H., Fujisawa, C., and Bhadhprasit, W. (2011). Pathology, clinical features and treatments of congenital copper metabolic disorders-focus on neurologic aspects. Brain Dev. 33, 243-251. doi: 10.1016/j.braindev.2010.10.021

Kodama, H., Fujisawa, C., and Bhadhprasit, W. (2012). Inherited copper transport disorders: biochemical mechanisms, diagnosis and treatment. Curr. Drug. Metab. 13, 237-250. doi: 10.2174/138920012799320455

Kodama, H., Sato, E., Gu, Y. H., Shiga, K., Fujisawa, C., and Kozuma, T. (2005). Effect of copper and diethyldithiocarbamate combination therapy on the macular mouse, an animal model of Menkes disease. J. Inherit. Metab. Dis. 28, 971-978. doi: 10.1007/s10545-005-0150-6

Kowal, M., Lenartowicz, M., Pecio, A., Gołas, A., Błaszkiewicz, T., and Styrna, J. (2010). Copper metabolism disorders affect testes structure and gamete quality in male mice. Syst. Biol. Reprod. Med. 56, 431-444. doi: 10. 3109/19396361003734624

Kuivaniemi, H., Peltonen, L., and Kivirikko, K. I. (1985). Type IX Ehlers-Danlos syndrome and Menkes syndrome: the decrease in lysyl oxidase activity is associated with a corresponding deficiency in the enzyme protein. Am. J. Hum. Genet. 37, 798-808.

Kuo, Y. M., Gitshier, J., and Packman, S. (1997). Developmental expression of the mouse mottled and toxic milk genes suggest distinct functions for the Menkes and Wilson disease copper transporters. Hum. Mol. Genet. 6, 1043-1049. doi: $10.1093 / \mathrm{hmg} / 6.7 .1043$

La Fontaine, S., Firth, S. D., Lockhart, P. J., Brooks, H., Camacaris, J., and Mercer, J. F. (1999). Intracellular localization and loss of copper responsivenessof Mnk, the murine homology of the Menkes protein, in cells from blotchy $\left(\mathrm{Mo}^{\text {blo }}\right)$ and brindled $\left(\mathrm{Mo}^{b r}\right)$ mouse mutants. Hum. Mol. Genet. 8, 1069-1075. doi: 10. 1093/hmg/8.6.1069

La Fontaine, S., and Mercer, J. F. (2007). Trafficking of the copper-ATPases, ATP7A and ATP7B: role in copper homeostasis. Arch. Biochem. Biophys. 463, 149-167. doi: 10.1016/j.abb.2007.04.021

Lenartowicz, M., Grzmil, P., Rusin, M., and Styrna, J. (2004). Alternative splicing in the Atp7a gene in the $\mathrm{Cu}$ deficient mosaic mutation in mice. Folia Biol. (Krakow) 52, 219-223. doi: 10.3409/1734916044527610

Lenartowicz, M., Grzmil, P., Shoukier, M., Starzyński, R., Marciniak, M. and Lipiński, P. (2012a). Mutation in the CPC motif-containing 6th transmembrane domain affects intracellular localization, trafficking and copper transport efficiency of ATP7A protein in mosaic mutant micean animal model of Menkes disease. Metallomics 4, 197-204. doi: 10. $1039 / \mathrm{clmt} 00134 \mathrm{e}$

Lenartowicz, M., Krzeptowski, W., Koteja, P., Chrząścik, K., and Moller, L. B. (2012b). Prenatal treatment of mosaic mice (Atp7a mo-ms) mouse model for Menkes disease, with copper combined by dimethyldithiocarbamate (DMDT). PLoS One 7:e40400. doi: 10.1371/journal.pone.0040400

Lenartowicz, M., Kowal, M., Buda-Lewandowska, D., and Styrna, J. (2002). Pathological structure of the kidney from the adult mice with mosaic mutation. J. Inherit. Metab. Dis. 25, 647-659. doi: 10.1023/A:1022877130344

Lenartowicz, M., and Sasuła, K. (2000). Altered copper metabolism in the mosaic mutant mice. Nutr. Res. 10, 1519-1529. doi: 10.1016/s0271-5317(00) 00230-x

Lenartowicz, M., Sasuła, K., and Zawadowska, B. (2001). Alterations in kidney morphology in mice with mosaic mutation. Folia Histochem. Cytobiol. 39, 275-281.

Lenartowicz, M., Starzyński, R. R., Krzeptowski, W., Grzmil, P., Bednarz, A., Ogórek, M., et al. (2014). Haemolysis and perturbations in the systemic iron metabolism of suckling, copper-deficient mosaic mutant mice-an animal model of Menkes disease. PLoS One 9:e107641. doi: 10.1371/journal.pone. 0107641

Lenartowicz, M., Starzyński, R., Wieczerzak, K., Krzeptowski, W., Lipiński, P., and Styrna, J. (2011). Alterations in the expression of the Atp7a gene in the early postnatal development in the mosaic mutant mice $\left(A t p 7 a^{m o-m s}\right)$-an animal model of Menkes disease. Gene. Expr. Patterns 11, 41-47. doi: 10.1016/j.gep. 2010.09.001

Lenartowicz, M., Windak, R., Tylko, G., Kowal, M., and Styrna, J. (2010). Effects of copper supplementation on the structure and content of elements in kidneys of mosaic mutant mice. Biol. Trace Elem. Res. 136, 204-220. doi: 10.1007/s12011009-8533-4

Leung, K. P., Chen, D., and Chan, K. M. (2014). Understanding copper sensitivity in zebrafish (Danio rerio) through the intracellular localization of copper transporters in a hepatocyte cell-line ZFL and the tissue expression profiles of copper transporters. Metallomics 6, 1057-1067. doi: 10.1039/c3mt00366c

Levinson, B., Vulpe, C., Elder, B., Martin, C., Verley, F., Packman, S., et al. (1994). The mottled gene is the mouse homolog of the Menkes disease gene. Nat. Genet. 6, 369-373. doi: 10.1038/ng0494-369

Linz, L., and Lutsenko, S. (2007). Copper-transporting ATP-ases ATP7A and ATP7B cousins, not twins. J. Bioenerg. Biomembr. 39, 403-407. doi: 10. 1007/s10863-007-9101-2

Lipríski, P., Styś, A., and Starzyński, R. R. (2013). Molecular insights into the regulation of iron metabolism during the prenatal and early postnatal periods. Cell. Mol. Life Sci. 70, 23-38. doi: 10.1007/s00018-012-1018-1

Llanos, R. M., Ke, B. X., Wright, M., Deal, Y., Monty, F., Kremer, D. R., et al. (2006). Correction of a mouse model of human Menkes disease by human Menkes gene. Biochim. Biophys. Acta 1762, 485-493. doi: 10.1016/j.bbadis.2005.12.011

Lopez, V., Suzuki, Y. A., and Lönnerdal, B. (2006). Ontogenic changes in lactoferrin receptor and DMT1 in mouse small intestine: implications for iron absorption during early life. Biochem. Cell Biol. 84, 337-344. doi: 10.1139/ o06-059

Lutsenko, S., Barnes, N. L., Bartee, M. Y., and Dymitriev, O. Y. (2007). Function and regulation of human copper-transporting ATPases. Physiol. Rev. 87, 1011-1046. doi: 10.1152/physrev.00004.2006

Lutsenko, S., Bhattacharjee, A., and Hubbard, A. L. (2010). Copper handling machinery of the brain. Metallomics 2, 596-608. doi: $10.1039 / \mathrm{c} 0 \mathrm{mt}$ 00006j

Lyon, M. F. (1962). Sex chromatin and gene action in the mammalian Xchromosome. Am. J. Hum. Genet. 14, 135-148. 
Madsen, E. C., and Gitlin, J. D. (2008). Zebrafish mutants calamity and catastrophe define critical pathways of gene-nutrient interactions in developmental copper metabolism. PLoS Genet. 4:e1000261. doi: 10.1371/journal.pgen. 1000261

Madsen, E. C., Morcos, P. A., Mendelsohn, B. A., and Gitlin, J. D. (2008). In vivo correction of a Menkes disease model using antisense oligonucleotides. Proc. Natl. Acad. Sci. U S A 105, 3909-3914. doi: 10.1073/pnas.0710865105

Marchler-Bauer, A., Derbyshire, M. K., Gonzales, N. R., Lu, S., Chitsaz, F., Geer, L. Y., et al. (2015). CDD: NCBI's conserved domain database. Nucleic Acids Res. 43, D222-D226. doi: 10.1093/nar/gku1221

McArdle, H. J., and Erlich, R. (1991). Copper uptake and transfer to the mouse fetus during pregnancy. J. Nutr. 121, 208-214.

Mendelsohn, B. A., Yin, C., Johnson, S. L., Wilm, T. P., Solnica-Krezel, L., and Gitlin, J. D. (2006). Atp7a determines a hierarchy of copper metabolism essential for notochord development. Cell Metab. 4, 155-162. doi: 10.1016/j. cmet.2006.05.001

Menkes, J. H., Alter, M., Steigleder, G. K., Weakley, D. R., and Sung, J. H. (1962). A sex-linked recessive disorder with retardation of growth, peculiar hair and focal cerebral and cerebellar degeneration. Pediatrics 29, 764-779.

Mercer, J. F., Ambrosini, L., Horton, S., Gazeas, S., and Grimes, A. (1999). Animal models of Menkes disease. Adv. Exp. Med. Biol. 448, 97-108. doi: 10.1007/9781-4615-4859-1_8

Mercer, J. F. B., Grimes, A., Ambrosini, L., Lockhart, P., Paynter, J. A., Dierick, H., et al. (1994). Mutations in the murine homologue of the Menkes gene in dappled and blotchy mice. Nat. Genet. 6, 374-378. doi: 10.1038/ng0494-374

Mercer, J. F., Grimes, A., and Rauch, H. (1992). Hepatic metallothionein gene expression in toxic milk mice. J. Nutr. 122, 1254-1259.

Møller, L. B., Bukrinsky, J. T., Mølgaard, A., Paulsen, M., Lund, C., Tümer, Z., et al. (2005). Identification and analysis of 21 novel disease-causing amino acid substitutions in the conserved part of ATP7A. Hum. Mutat. 26, 84-93. doi: 10. 1002/humu.20190

Møller, L. B., Mogensen, M., and Horn, N. (2009). Molecular diagnosis of Menkes disease: genotype-phenotype correlation. Biochimie 91, 1273-1277. doi: 10. 1016/j.biochi.2009.05.011

Møller, L. B., Tümer, Z., Lund, C., Petersen, C., Cole, T., Hanusch, R., et al. (2000). Similar splice-site mutations of the ATP7A gene lead to different phenotypes: classical Menkes disease or occipital horn syndrome. Am. J. Hum. Genet. 66, 1211-1220. doi: 10.1086/302857

Mori, M., and Nishimura, A. (1997). A serine-to-proline mutation in the coppertransporting P-type ATPase gene of the macular mouse. Mamm. Genome 8, 407-410. doi: 10.1007/s003359900457

Mototani, Y., Miyoshi, I., Okamura, T., Moriya, T., Meng, Y., Yuan Pei, X., et al. (2006). Phenotypic and genetic characterization of the Atp7a(Mo-Tohm) mottled mouse: a new murine model of Menkes disease. Genomics 87, 191-199. doi: 10.1016/j.ygeno.2005.09.011

Munakata, M., Kodama, H., Fujisawa, C., Hiroki, T., Kimura, K., Watanabe, M., et al. (2012). Copper-trafficking efficacy of copper-pyruvaldehyde bis(N4methylthiosemicarbazone) on the macular mouse, an animal model of Menkes disease. Pediatr. Res. 72, 270-276. doi: 10.1038/pr.2012.85

Murata, Y., Kodama, H., Abe, T., Ishida, N., Nishimura, M., Lewinson, B., et al. (1997). Mutation analysis and expression of the mottled gene in the macular mouse model of Menkes disease. Pediatr. Res. 42, 436-442. doi: 10. 1203/00006450-199710000-00003

Nadal, D., and Baerlocher, K. (1988). Menkes' disease: long-term treatment with copper and D-penicillamine. Eur. J. Pediatr. 147, 621-625. doi: 10. 1007/bf00442477

Nakagawa, S., Adachi, R., Mijake, M., Hama, T., Tanaka, K., and Mayumi, T. (1993). Production of normal macular mouse chimeras: the presence of critical tissue in the macular mutant mouse, a model of Menkes' kinky hair disease. Zool. Scie. 10, 653-660.

Nelson, K. T., and Prohaska, J. R. (2009). Copper deficiency in rodents alters dopamine beta-mono-oxygenase activity, mRNA and protein level. Br. J. Nutr. 102, 18-28. doi: 10.1017/s0007114508162961

Niciu, M. J., Ma, X. M., El Meskini, R., Pachter, J. S., Mains, R. E., and Eipper, B. A. (2007). Altered ATP7A expression and other compensatory responses in a murine model of Menkes disease. Neurobiol. Dis. 27, 278-291. doi: 10.1016/j. nbd.2007.05.004

Niciu, M. J., Ma, X. M., El Meskini, R., Ronnett, G. V., Mains, R. E., and Eipper, B. A. (2006). Developmental changes in the expression of the Atp7a during a critical period in postnatal neurodevelopment. Neuroscience 139, 947-964. doi: 10.1016/j.neuroscience.2006.01.044

Nie, Y., Schoepp, D. D., Klaunig, J. E., Yard, M., Lahiri, D. K., and Kubek, M. J. (2005). Thyrotropin-releasing hormone (protirelin) inhibits potassium-stimulated glutamate and aspartate release from hippocampal slices in vitro. Brain Res. 1054, 45-54. doi: 10.1016/j.brainres.2005.06.077

Norgate, M., Lee, E., Southon, A., Farlow, A., Batterham, P., Camakaris, J., et al. (2006). Essential roles in development and pigmentation for the Drosophila copper transporter DmATP7. Mol. Biol. Cell 17, 475-484. doi: 10.1091/mbc. e05-06-0492

Norgate, M., Southon, A., Zou, S., Zhan, M., Sun, Y., Batterham, P., et al. (2007). Copper homeostasis gene discovery in Drosophila melanogaster. Biometals 20 , 683-697. doi: 10.1007/s10534-006-9075-2

Otoikhian, A., Barry, A. N., Mayfield, M., Nilges, M., Huang, Y., Lutsenko, S., et al. (2012). Lumenal loop M672-P707 of the Menkes protein (ATP7A) transfers copper to peptidylglycine monooxygenase. J. Am. Chem. Soc. 134, 10458-10468. doi: 10.1021/ja301221s

Patel, B. N., and David, S. (1997). A novel glycosylphosphatidylinositol-anchored form of ceruloplasmin is expressed by mammalian astrocytes. J. Biol. Chem 272, 20185-20190. doi: 10.1074/jbc.272.32.20185

Petris, M. J., Strausak, D., and Mercer, J. F. (2000). The Menkes copper transporter is required for the activation of tyrosinase. Hum. Mol. Genet. 9, 2845-2851. doi: 10.1093/hmg/9.19.2845

Phillips, M., Camakaris, J., and Danks, D. M. (1986). Comparisons of copper deficiency states in the murine mutants blotchy and brindled. Changes in copper-dependent enzyme activity in 13-day-old mice. Biochem. J. 238, 177-183. doi: 10.1042/bj2380177

Phillips, M., Camakaris, J., and Danks, D. M. (1991). A comparison of phenotype and copper distribution in blotchy and brindled mutant mice and in nutritionally copper deficient controls. Biol. Trace Elem. Res. 29, 11-29. doi: 10. 1007/bf03032670

Phillips, J. B., and Westerfield, M. (2014). Zebrafish models in translational research: tipping the scales toward advancements in human health. Dis. Model. Mech. 7, 739-743. doi: 10.1242/dmm.015545

Poulsen, L., Horn, N., Heilstrup, H., Lund, C., Tümer, Z., and Møller, L. B. (2002). $\mathrm{X}$-linked recessive Menkes disease: identification of partial gene deletions in affected males. Clin. Genet. 62, 449-457. doi: 10.1034/j.1399-0004.2002. 620605.x

Prasad, A. N., Levin, S., Rupar, C. A., and Prasad, C. (2011). Menkes disease and infantile epilepsy. Brain Dev. 33, 866-876. doi: 10.1016/j.braindev.2011.08.002

Prohaska, J. R. (1983). Changes in tissue growth, concentrations of copper, iron, cytochrome oxidase and superoxide dismutase subsequent to dietary or genetic copper deficiency in mice. J. Nutr. 113, 2048-2058.

Prohaska, J. R. (1988). Effect of dietary copper deficiency on heterozygous female brindled mice. Nutr. Res. 8, 1079-1084. doi: 10.1016/s0271-5317(88)80063-0

Prohaska, J. R. (2011). Impact of copper limitation on expression and function of multicopper oxidases (ferroxidases). Adv. Nutr. 2, 89-95. doi: 10.3945/an.110. 000208

Prohaska, J. R., and Broderius, K. (2006). Plasma peptidylglycine alpha-amidating monooxygenase (PAM) and ceruloplasmin are affected by age and copper status in rats and mice. Comp. Biochem. Physiol. B Biochem. Mol. Biol. 143, 360-366. doi: 10.1016/j.cbpb.2005.12.010

Proud, V. K., Mussell, H. G., Kaler, S. G., Young, D. W., and Percy, A. K. (1996). Distinctive Menkes disease variant with occipital horns: delineation of natural history and clinical phenotype. Am. J. Med. Genet. 65, 44-51. doi: 10. 1002/(sici)1096-8628(19961002)65:1<44::aid-ajmg7>3.0.co;2-y

Qi, M., and Byers, P. H. (1998). Constitutive skipping of alternatively spliced exon 10 in the ATP7A gene abolishes Golgi localization of the Menkes protein and produces the occipital horn syndrome. Hum. Mol. Genet. 7, 465-469. doi: 10. 1093/hmg/7.3.465

Reed, V., and Boyd, Y. (1997). Mutation analysis provides additional proof that mottled is the mouse homolog of Menkes disease. Hum. Mol. Genet. 6, 417-423. doi: $10.1093 / \mathrm{hmg} / 6.3 .417$

Richichi, C., Lin, E. J., Stefanin, D., Colella, D., Ravizza, T., Grignaschi, G., et al. (2004). Anticonvulsant and antiepileptogenic effects mediated by adenoassociated virus vector neuropeptide Y expression in the rat hippocampus. J. Neurosci. 24, 3051-3059. doi: 10.1523/jneurosci.4056-03.2004

Rowe, D. W., McGoodwin, E. B., Martin, G. R., Sussman, M. D., Grahn, D., Faris, B., et al. (1974). A sex-linked defect in the cross-linking of collagen and elastin 
associated with the mottled locus in mice. J. Exp. Med. 139, 180-192. doi: 10. 1084/jem.139.1.180

Royce, P. M., Camakaris, J., Mann, J. R., and Danks, D. M. (1982). Copper metabolism in mottled mouse mutants. The effect of copper therapy on lysyl oxidase activity in brindled (Mobr) mice. Biochem. J. 202, 369-371. doi: 10. 1042/bj2020369

Royce, P. M., and Steinmann, B. (1990). Markedly reduced activity of lysyl oxidase in skin and aorta from a patient with Menkes' disease showing unusually severe connective tissue manifestations. Pediatr. Res. 28, 137-141. doi: 10. 1203/00006450-199008000-00012

Rucker, R. B., Kosonen, T., Clegg, M. S., Mitchell, A. E., Rucker, B. R., Uriu-Hare, J. Y., et al. (1998). Copper, lysyl oxidase and extracellular matrix protein crosslinking. Am. J. Clin. Nutr. 67, S996-S1002.

Sellami, A., Wegener, C., and Veenstra, J. A. (2012). Functional significance of the copper transporter ATP7 in peptidergic neurons and endocrine cells in Drosophila melanogaster. FEBS Lett. 586, 3633-3638. doi: 10.1016/j.febslet. 2012.08.009

Shibata, N., Hirano, A., Kobayashi, M., Umahara, T., Kawanami, T., and Asayama, K. (1995). Cerebellar superoxide dismutase expression in Menkes' kinky hair disease: an immunohistochemical investigation. Acta Neuropathol. 90, 198-202. doi: 10.1007/bf00294321

Shiraishi, N., Aono, K., and Tagauchi, T. (1988). Copper metabolism in the macular mutant mouse: an animal model of Menkes Kinky-Hair disease. Biol. Neonate 54, 173-180. doi: 10.1159/000242849

Silberberg, R. (1977). Epiphyseal growth and osteoarthrosis in blotchy mice. Exp. Cell Biol. 45, 1-8. doi: 10.1159/000162853

Silvers, W. K. (ed.). (1979). "X-linked determinants," in The Coat Colour of Mice, Model for Mammalian Gene Action and Interaction, (New York: SpringerVerlag), 159-184.

Skjørringe, T., Tümer, Z., and Møller, L. B. (2011). Splice site mutations in the ATP7A gene. PLoS One 11:e18599. doi: 10.1371/journal.pone.0018599

Southon, A., Burke, R., Norgate, M., Batterham, P., and Camakaris, J. (2004). Copper homoeostasis in Drosophila melanogaster S2 cells. Biochem. J. 383, 303-309. doi: 10.1042/bj20040745

Southon, A., Palstra, N., Veldhuis, N., Gaeth, A., Robin, C., Burke, R., et al. (2010). Conservation of copper-transporting P(IB)-type ATPase function. Biometals 23, 681-694. doi: 10.1007/s10534-010-9332-2

Steveson, T. C., Ciccotosto, G. D., Ma, X. M., Mueller, G. P., Mains, R. E., and Eipper, B. A. (2003). Menkes protein contributes to the function of peptidylglycine $\alpha$-amidating monooxygenase. Endocrinology 144, 188-200. doi: 10.1210/en.2002-220716

Styrna, J. (1977). Analysis of causes of lethality in mice with Ms (mosaic) gene. Genet. Polon. 18, 61-79.

Suzuki, M., and Gitlin, J. D. (1999). Intracellular localization of Menkes and Wilson disease proteins and their intracellular copper transport. Pediatr. Int. 41, 436-442. doi: 10.1046/j.1442-200x.1999.01090.x

Suzuki-Kurasaki, M., Okabe, M., and Kurasaki, M. (1997). Copper-metallotionein in the kidney of macular mice: a model for Menkes disease. J. Histochem. Cytochem. 45, 1493-1501. doi: 10.1177/002215549704501106

Tanaka, K., Kobayashi, K., Fuita, Y., Fukuhara, C., Onosaka, S., and Min, K. (1990). Effects of chelators on copper therapy of macular mouse, a model animal of Menkes' kinky disease. Res. Commun. Chem. Phatol. Pharmacol. 69, 217-227.

Tang, J., Robertson, S., Lem, K. E., Godwin, S. C., and Kaler, S. G. (2006). Functional copper transport explains neurologic sparing in occipital horn syndrome. Genet. Med. 8, 711-718. doi: 10.1097/01.gim.0000245578.94312.1e

Telianidis, J., Hung, Y. H., Materia, S., and Fontaine, S. L. (2013). Role of the PType ATPases, ATP7A and ATP7B in brain copper homeostasis. Front. Aging Neurosci. 5:44. doi: 10.3389/fnagi.2013.00044

Tümer, Z. (2013). An overview and update of ATP7A mutations leading to Menkes disease and occipital horn syndrome. Hum. Mutat. 34, 417-429. doi: 10. 1002/humu.22266

Tümer, Z., Birk Møller, L., and Horn, N. (2003). Screening of 383 unrelated patients affected with Menkes disease and finding of 57 gross deletions in ATP7A. Hum. Mutat. 22, 457-464. doi: 10.1002/humu.10287
Tümer, Z., Horn, N., Tønnesen, T., Christodoulou, J., Clarke, J. T., and Sarkar, B. (1996). Early copper-histidine treatment for Menkes disease. Nat. Genet. 12, 11-13. doi: 10.1038/ng0196-11

Tümer, Z., and Møller, L. B. (2010). Menkes disease. Eur. J. Hum. Genet. 5, 511-518. doi: 10.1038/ejhg.2009.187

van den Berghe, P. V., and Klomp, L. W. (2010). Posttranslational regulation of copper transporters. J. Biol. Inorg. Chem. 15, 37-46. doi: 10.1007/s00775-0090592-7

Veronesi, M. C., Kubek, D. J., and Kubek, M. J. (2007). Intranasal delivery of a thyrotropin-releasing hormone analog attenuates seizures in the amygdalakindled rat. Epilepsia 48, 2280-2286. doi: 10.1111/j.1528-1167.2007.01218.x

Verrotti, A., Cusmai, R., Darra, F., Martelli, P., Accorsi, P., Bergamo, S., et al. (2014). Epilepsy in Menkes disease: an electroclinical long-term study of 28 patients. Epilepsy Res. 108, 1597-1603. doi: 10.1016/j.eplepsyres.2014. 08.006

Viatte, L., and Vaulont, S. (2009). Hepcidin, the iron watcher. Biochimie 91, 1223-1228. doi: 10.1016/j.biochi.2009.06.012

Vulpe, C. D., Kuo, Y. M., Murphy, T. L., Cowley, L., Askwith, C., Libina, N., et al. (1999). Hephaestin, a ceruloplasmin homologue implicated in intestinal iron transport, is defective in the sla mouse. Nat. Genet. 21, 195-199. doi: 10. $1038 / 5979$

Wenk, G., and Suzuki, K. (1983). Congenital copper deficiency: copper therapy and dopamine-beta-hydroxylase activity in the mottled (brindled) mouse. J. Neurochem. 41, 1648-1652. doi: 10.1111/j.1471-4159.1983.tb00876.x

White, S. R., Reese, K., Sato, S., and Kaler, S. G. (1993). Spectrum of EEG findings in Menkes disease. Electroencephalogr. Clin. Neurophysiol. 87, 57-61. doi: 10 1016/0013-4694(93)90175-u

Xu, G. Q., Yamano, T., and Shimada, M. (1994). Copper distribution in fetus and placenta of the macular mutant mouse as a model of Menkes kinky hair disease. Biol. Neonate 66, 302-310. doi: 10.1159/000244121

Yamano, T., Shimada, M., Kawasaki, H., Onaga, A., and Nishimura, M. (1987). Clinico-pathological study on macular mutant mouse. Acta Neuropathol. 72, 256-260. doi: 10.1007/bf00691098

Yi, L., and Kaler, S. (2014). ATP7A trafficking and mechanisms underlying the distal motor neuropathy induced by mutations in ATP7A. Ann. N Y Acad. Sci. 1314, 49-54. doi: 10.1111/nyas.12427

Yoshida, K., Furihata, K., Takeda, S., Nakamura, A., Yamamoto, K., Morita, H., et al. (1995). A mutation in the ceruloplasmin gene is associated with systemic hemosiderosis in humans. Nat. Genet. 9, 267-272. doi: 10.1038/ ng0395-267

Zaffanello, M., Maffeis, C., Fanos, V., Franchini, M., and Zamboni, G. (2006). Urological complication and copper replacement in childhood Menkes syndrome. Acta Pediatr. 95, 785-790. doi: 10.1111/j.1651-2227.2006. tb02341.x

Zelko, I. N., Marian, T. J., and Folz, R. J. (2002). Superoxide dismutase multigene family: a comparison of the CuZn-SOD (SOD1), Mn-SOD (SOD2) and ECSOD (SOD3) gene structures, evolution and expression. Free Radic. Biol. Med. 33, 337-349. doi: 10.1016/s0891-5849(02)00905-x

Zheng, W., and Monnot, A. D. (2012). Regulation of brain iron and copper homeostasis by brain barrier systems: implication in neurodegenerative diseases. Pharmacol. Ther. 133, 177-188. doi: 10.1016/j.pharmthera.2011. 10.006

Conflict of Interest Statement: The authors declare that the research was conducted in the absence of any commercial or financial relationships that could be construed as a potential conflict of interest.

Copyright (C) 2015 Lenartowicz, Krzeptowski, Lipiński, Grzmil, Starzyński, Pierzchała and Møller. This is an open-access article distributed under the terms of the Creative Commons Attribution License (CC BY). The use, distribution and reproduction in other forums is permitted, provided the original author(s) or licensor are credited and that the original publication in this journal is cited, in accordance with accepted academic practice. No use, distribution or reproduction is permitted which does not comply with these terms. 